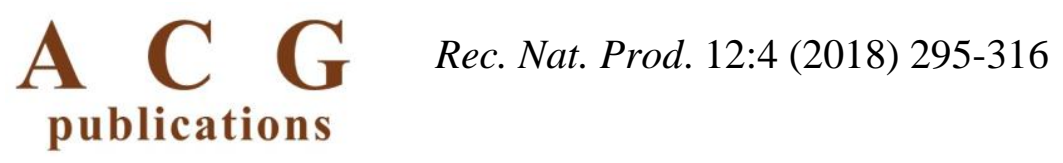

\title{
Plant-Derived Antimicrobials: Insights into Mitigation of Antimicrobial Resistance
}

\author{
Shun-Kai Yang ${ }^{1}$, Lee-Yoon Low ${ }^{1}$, Polly Soo-Xi Yap ${ }^{6}$, Khatijah Yusoff ${ }^{2}$, \\ Chun-Wai Mai ${ }^{3}$, Kok-Song Lai ${ }^{1}$ and Swee-Hua Erin Lim $^{4,5,7^{*}}$
}

\author{
${ }^{1}$ Department of Cell and Molecular Biology, Faculty of Biotechnology and Biomolecular Sciences, \\ University Putra Malaysia, 43400 Serdang, Selangor, Malaysia \\ ${ }^{2}$ Department of Microbiology, Faculty of Biotechnology and Biomolecular Sciences, University Putra \\ Malaysia, 43400 Serdang, Selangor, Malaysia \\ ${ }^{3}$ Department of Pharmaceutical Chemistry, School of Pharmacy, International Medical University, \\ Bukit Jalil, 57000, Kuala Lumpur, Malaysia \\ ${ }^{4}$ Centre for Bioinformatics, School of Data Sciences, Perdana University, MAEPS Building, Serdang, \\ Selangor, Malaysia \\ ${ }^{5}$ Perdana University-Royal College of Surgeons in Ireland, Perdana University, MAEPS Building, \\ Serdang, Selangor, Malaysia \\ ${ }^{6}$ School of Postgraduate Studies and Research, International Medical University, No. 126, Jalan Jalil \\ Perkasa 19, Bukit Jalil, 57000 Kuala Lumpur, Malaysia \\ ${ }^{7}$ Health Sciences Division, Abu Dhabi Women's College, Higher Colleges of Technology, Abu Dhabi, \\ United Arab Emirates
}

(Received September 17, 2017; Revised December 12, 2017; Accepted December 12, 2017)

\begin{abstract}
Antibiotic resistance had first been reported not long after the discovery of the first antibiotic and has remained a major public health issue ever since. Challenges are constantly encountered during the mitigation process of antibiotic resistance in the clinical setting; especially with the emergence of the formidable superbug, a bacteria with multiple resistance towards different antibiotics; this resulted in the term multidrug resistant (MDR) bacteria. This rapid evolution of the resistance phenomenon has propelled researchers to continuously uncover new antimicrobial agents in a bid to hopefully, downplay the rate of evolution despite a drying pipeline. Recently, there has been a paradigm shift in the mining of potential antimicrobials; in the past, targets for drug discovery were from microorganisms and at current, the focus has moved onto plants, this is mainly due to the beneficial attributes that plants are able to confer over that of microorganisms. This review will briefly discuss antibiotic resistance mechanisms employed by resistant bacteria followed by a detailed expository regarding the use of secondary metabolites from plants as a potential solution to the MDR pathogen. Finally, future prospects recommending enhancements to the usage of plant secondary metabolites to directly target antibiotic resistant pathogens will be discussed.
\end{abstract}

Keywords: Antimicrobial resistance; plant metabolites; resistance reversal; synergism. (c) 2018 ACG Publications. All rights reserved.

\footnotetext{
* Corresponding author: E-Mail: erinlim@ perdanauniversity.edu.my; Phone: +60389418646 ext. 178 Fax: $+60389417661$
}

The article was published by ACG Publications 


\section{Introduction}

In the early $20^{\text {th }}$ century, penicillin, the first natural compound exhibiting antibiotic properties, was discovered accidentally by the pharmacologist, Alexander Fleming when he observed the growth of bacterial colonies in the presence of an antibiotic-secreting fungus [2] [1]. Antibiotic resistance was reported fairly rapidly in the same year in 1928. This stroke of luck revolutionized the medical field ever since; leading to the discovery of other classes of antibiotics such as streptomycin, chloramphenicol, erythromycin and chlortetracycline [4]. However, antibiotics today are no longer the miracle drugs they used to be due to the emergence of resistance to antibiotics amongst bacteria.

Emergence of antibiotic resistance bacteria is mainly due to the lack of compliance by consumers as well as healthcare practitioners. Furthermore, easy access to unauthorized medical distributors allows ready procurement of antibiotics by the general public, intensifying the problem. Improperly trained drug prescribers as well as inconsistencies of available standardized treatment guidelines contributed to this phenomenon. Moreover, the extensive and unmonitored use of excessive antibiotics in the field of agriculture and aquaculture has also accelerated the rates of development of antibiotic resistance in pathogens [5].

Natural selection was first theorized by Charles Darwin; he theorized that the survival of the fittest individual is attributed to its genotypic and phenotypic differences; possession of these traits enables the particular individuals to survive harsh environments [6]. In the same way, constant selective stress from antibiotics on bacteria can either kill them or enable their survival; this occurs via mutations or direct horizontal transfers between closely and distantly related species [7] culminating in the up-regulation of antibiotic resistant genes or protective protein production such as efflux pumps. Most bacteria possess a short doubling time, and this very attribute that promotes survivability and sustainability also accelerates the evolutionary trajectory of antibiotic resistance.

Antibiotic-resistant pathogens have caused significant detrimental effects towards mankind; this increases the mortality rates of patients, contributing to infections as a direct result of non-efficacious common antibiotic dosages. This inadvertently may result in escalated treatment costs as well as more adverse side effects when physicians resort to lesser used second or previously rejected line of antibiotics such as daptomycin [4]. With recent advancement in science and technology, the discovery of novel drugs is not as laborious as it used to be. However, the general public today are more health conscious and therefore, natural products are slowly becoming a popular mainstream platform for researchers to discovery newer, more effective antimicrobial drugs, considering the relatively reduced adverse effects and cost effectiveness of natural products, when developed at a commercial scale [8]. In this review, we will focus on antibiotic resistant strategies and mechanisms employed by bacteria as well as the potential utilization of plant secondary metabolites as a possibly effective solution to combat development of antimicrobial-resistance (AMR). In addition, synergistic relationships between plant secondary metabolites and existing antibiotics will be discussed in the subsequent sections.

\section{Strategies of Antibiotic Resistance}

Currently, commercialization and misuse of different antibiotics have triggered the emergence of superbugs otherwise known as multidrug resistant (MDR) bacteria. This occurrence and their presence especially in the clinical setting complicate administration of treatments during the course of infections. The issue of superbugs poses great threats and novel treatment methods are imperative and crucial in alleviating this problem. Therefore, an in-depth understanding of the strategies used by pathogenic bacteria to bypass antibiotic treatment is mandatory to adequately address this challenge.

\subsection{Modification of Antibiotic}

Antibiotics can be classified into three categories based on their localized mechanisms; either at the bacterial cell envelope, or at the cytoplasm during the protein synthesis process or at the genome of the bacteria. In response to preventing bacterial cell death, antibiotic modifying enzymes will be produced by these bacteria to modify activity of the applied antibiotics. For instance, bacteria resistant 
to $\beta$-lactam antibiotics produce $\beta$-lactamase, an enzyme capable of hydrolyzing the $\beta$-lactam core ring found in the structure of $\beta$-lactams, rendering the antibiotic ineffective. Examples of $\beta$-lactam antibiotics include penicillins, carbapenems, monobactams and cephalosporin.

The $\beta$-lactamase enzyme can be categorized into four classes: A, B, C and D. Classes A, C and $D$ are serine based $\beta$-lactamases while class B is a metal-based $\beta$-lactamase enzyme [9]. The active site of classes A, C and D $\beta$-lactamase consists of a serine molecule which acts as a nucleophile to attack the $\mathrm{C}-\mathrm{N}$ bond of the $\beta$-lactam ring. As the $\beta$-lactamase of classes $\mathrm{A}, \mathrm{C}$ and $\mathrm{D}$ reacts with the $\beta$-lactam antibiotic molecules, a covalent acyl-enzyme intermediate is formed; this is followed by hydrolysis via conserved deacylating water molecules (Figure 1.A). In contrast, the active site of the class B $\beta$ lactamase consists of the divalent cation, $\mathrm{Zn}^{2+}$ which requires water molecules for the disruption of the $\beta$-lactam ring (Figure 1.B). The covalent acyl-enzyme intermediate, however, is not formed in class B $\beta$-lactamase during hydrolysis of the $\beta$-lactam ring [10-11].

(A)
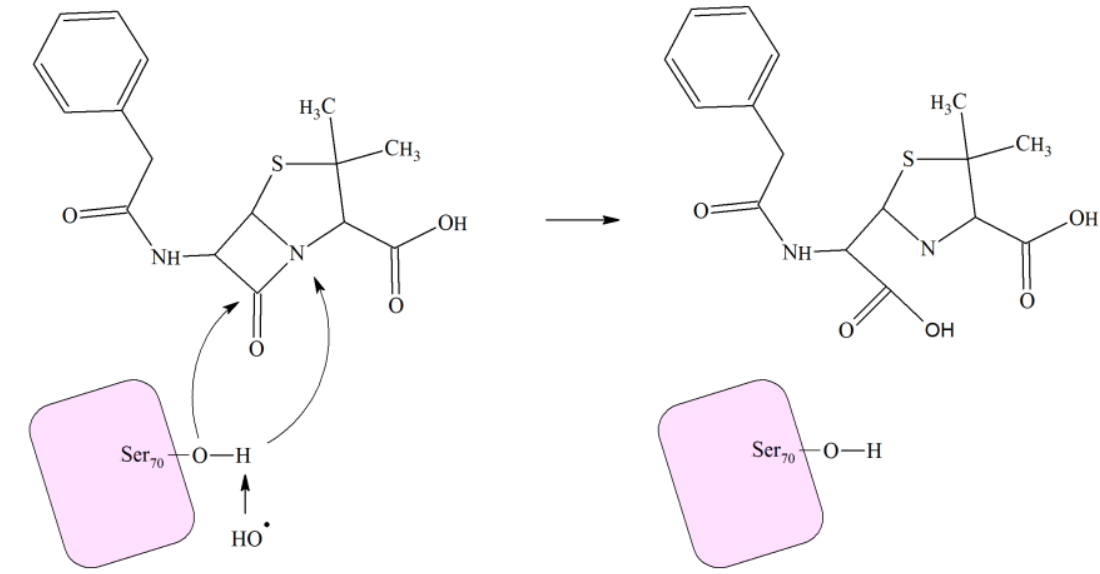

(B)
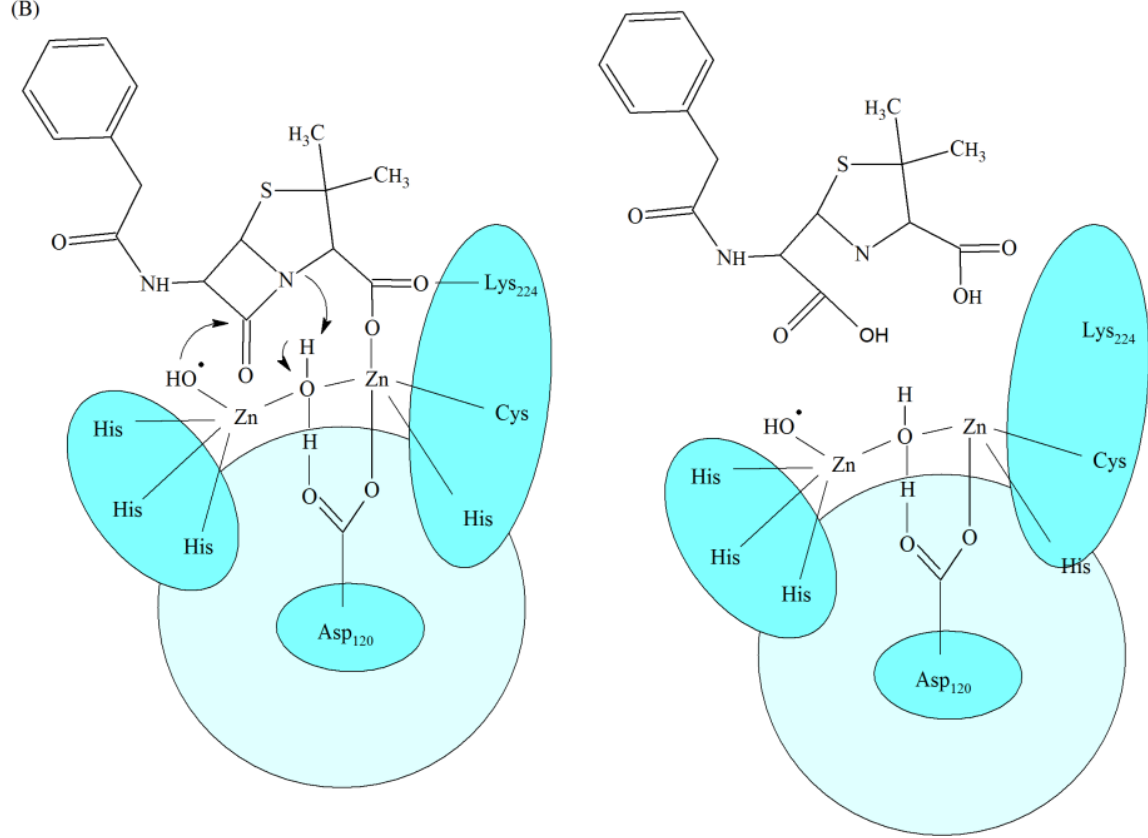

(A) Hydrolysis mechanism of penicillin by class A, C and D serine- $\beta$-lactamase. (B) Hydrolysis mechanism of penicillin by class B metallo- $\beta$-lactamase. Adapted from Drawz and Bonomo, 2010 [12].

Figure 1. Hydrolysis mechanisms of penicillin

In order to resolve the problem of antibiotic modification via the $\beta$-lactamase enzyme, several strategies have been employed. One of the more successful methods involves a combination treatment 
of $\beta$-lactam antibiotic with $\beta$-lactamase inhibitors such as clavulanic acid and tazobactam as illustrated in Figure 2 [12]. Inhibitors such as these share structural similarities with their antibiotic counterpart and are able to bind to the active site of $\beta$-lactamase enzyme with higher affinity, allowing the antibiotic to execute uninterrupted antimicrobial action [13-14].<smiles>CC1(C)SC2C(NCC(=O)c3ccccc3)C(=O)N2C1C(=O)O</smiles>

Penicillin<smiles>[X]OC(=O)C1/C(=C\CO)OC2CC(=O)N21</smiles>

Potassium Clavulanate<smiles>CC1(Cn2ccnn2)C(C(=O)ON)N2C(=O)CC2S1(=O)=O</smiles>

Tazobactam Sodium Salt

Figure 2. Chemical structure of penicillin and its analogue, potassium clavulanate and tazobactam

Modification of the structure of existing antibiotic is another successful method to resolve the $\beta$-lactamase enzyme issue. Newer generation cephalosporins have previously been modified with the removal of the aminoadipoyl sidechain to form 7-aminocephalosporanic acid (Fig. 3), rendering it 100-fold more effective than the older-generation cephalosporin [15-16]. This modification enabled cephalosporin to be less susceptible to hydrolysis by the $\beta$-lactamase enzyme [17].<smiles>CC(=O)OCC1=C(C(=O)O)N2C(=O)C(NC(=O)CCCC(N)C(=O)O)C2SC1</smiles>

Cephalosporin C<smiles>[R]OC(=O)OCC1=C(C(=O)O)N2C(=O)C(N)[C@H]2SC1</smiles>

7-aminocephalosporanic acid

Figure 3. Structural modification of cephalosporin C to key intermediate compound, 7aminocephalosporanic acid

7-aminocephalosporanic acid is required for the synthesis of multi-generation cephalosporins that is more effective and efficient than the cephalosporin predecessor.

\subsection{Modification of Antibiotic's Target Site}

Modification of the target site of antibiotics is another effective strategy employed by microorganisms to survive antibiotic treatment. Such strategy focuses on modification in terms of structure of the antibiotic target and this can occur in two different ways: via genetic mutation and/or post-transcriptional and translational modifications.

The first method, as illustrated in Figure 4, involves a slight gene mutation that changes the target site of the enzyme which then prevents or reduces the binding affinity of antibiotics but retains 
the function of the enzyme. $\beta$-lactam antibiotics such as penicillin mainly targets and inactivates the penicillin binding protein (PBP), a transpeptidase which aids in the cross-linking of peptidoglycan cell wall by acylating its active site. Mutation in the PBP gene, however, translates into a slightly different but functional protein which prevents the binding of $\beta$-lactam antibiotics such as penicillin [18-20]. Examples of microbes harboring this ability are drug-resistant strains of Clostridium difficile, Enterococcus faecium and Streptococcus pneumoniae [21-22]. In addition, microbial resistance towards ciprofloxacin, which interferes with cellular division through interaction between the DNA gyrase and topoisomerase, is also categorized under this mechanism [23-24].

(A)

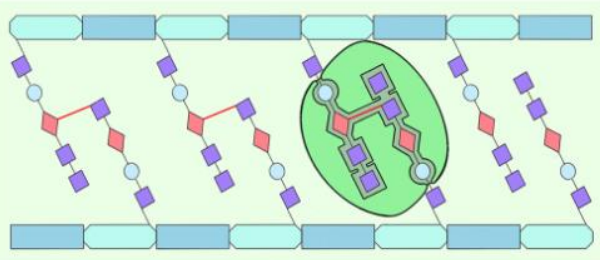

(B)
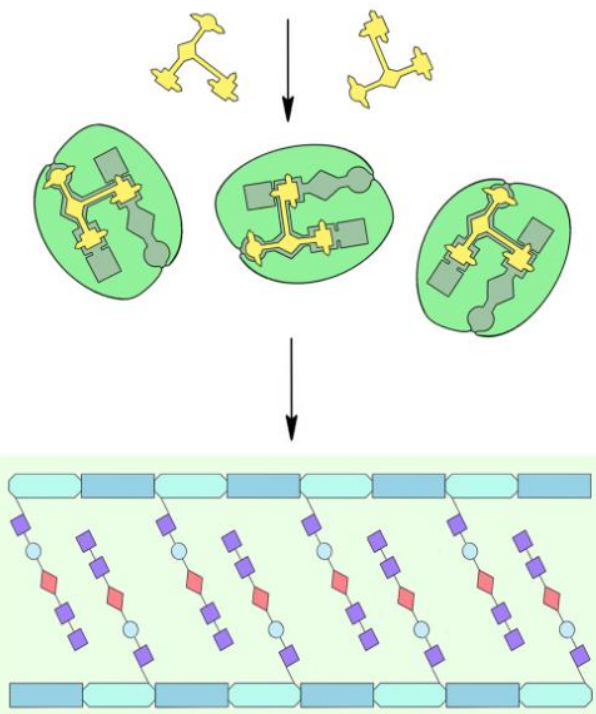

(C)
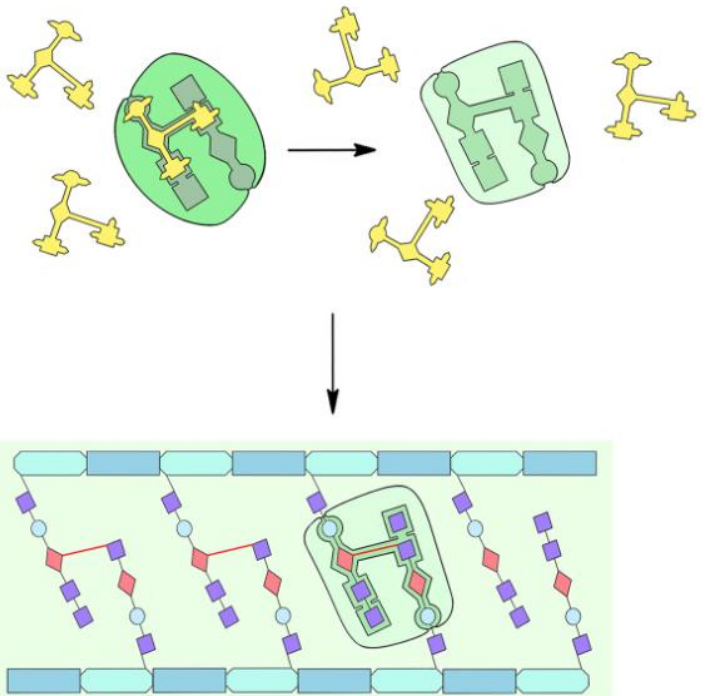

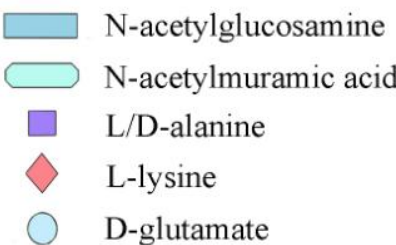

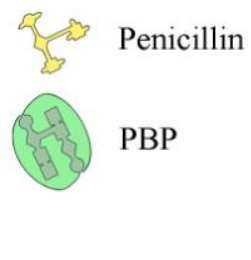

(A) Cross-linking of peptidoglycan precursors between L-lysine and L/D-alanine via the action of PBP. (B) Inhibition of PBP via high affinity binding of penicillin due to structural similarity with peptidoglycan precursors prevents the cross-linking of peptidoglycan precursors. $(\mathbf{C})$ Conformation changes in PBP due to gene mutation prevent the binding of penicillin but allow the PBP to carry out its designated function.

Figure 4. Processes detailing the modifications of PBP at the peptidoglycan

Antibiotic target site can also be modified via post-transcriptional and post-translational modifications; this confers resistance. Post-transcriptional modifications involve the alteration on the primary RNA transcript to form mature RNA which can then be translated into a functional protein. Post-translational modification, on the other hand, involves the enzymatic alteration of proteins followed by synthesis. Common post-transcriptional modifications in bacteria involve the methylation of tRNA anticodon stem loop which prevents frame shifting during translation [25]. It has been reported that methylation in specific $16 \mathrm{~S}$ ribosomal RNA prevents the binding of antibiotics such as spectinomycin and streptomycin, allowing normal protein translation [26-27]. Common posttranslational modifications in bacteria involve phosphorylation and succinylation of proteins. Sun and colleagues (2012) report that cysteine phosphorylation in eukaryotic-like kinases-phosphatase grants antibiotic resistance towards vancomycin and ceftriaxone in methicillin-resistant Staphylococcus aureus (MRSA) [28]. Furthermore, lysine succinylation in isocitrate lyase also confers antibiotic resistance towards rifampicin in Mycobacterium tuberculosis [29]. 


\subsection{Antibiotic Efflux Pump and Reduced Permeability}

Majority of the antibiotics available are only able to carry out their antimicrobial function when sufficient antibiotic molecules are transported across the cell membrane into the cytoplasm. Hence, another common antibiotic resistance strategy employed by bacteria involves the prevention of antibiotic accumulation in the cytoplasm, either through the overproduction of efflux pumps, which are embedded to the cytoplasmic membrane of bacteria, or through reduction in membrane permeability.

Efflux pumps are active transport proteins and function mainly to expel or to prevent the entry of toxic compounds; in this case, antibiotics, into the bacterial cytoplasm, with the help of energy either from adenosine triphosphate or an electrochemical potential gradient [20]. Bacteria such as Escherichia coli and Pseudomonas aeruginosa have been found to be extensively resistant to ciprofloxacin and fluoroquinolones due to the overexpression of proteins involved in the efflux pump system powered by the hydrogen ion gradient [30-31]. Rather than having an efflux pump system customized with antibiotic specificity, bacteria such as MRSA and $P$. aeruginosa express non-specific multidrug resistance pumps which efflux a range of antibiotics including the $\beta$-lactam antibiotics, as shown in figure 5 [32-34].

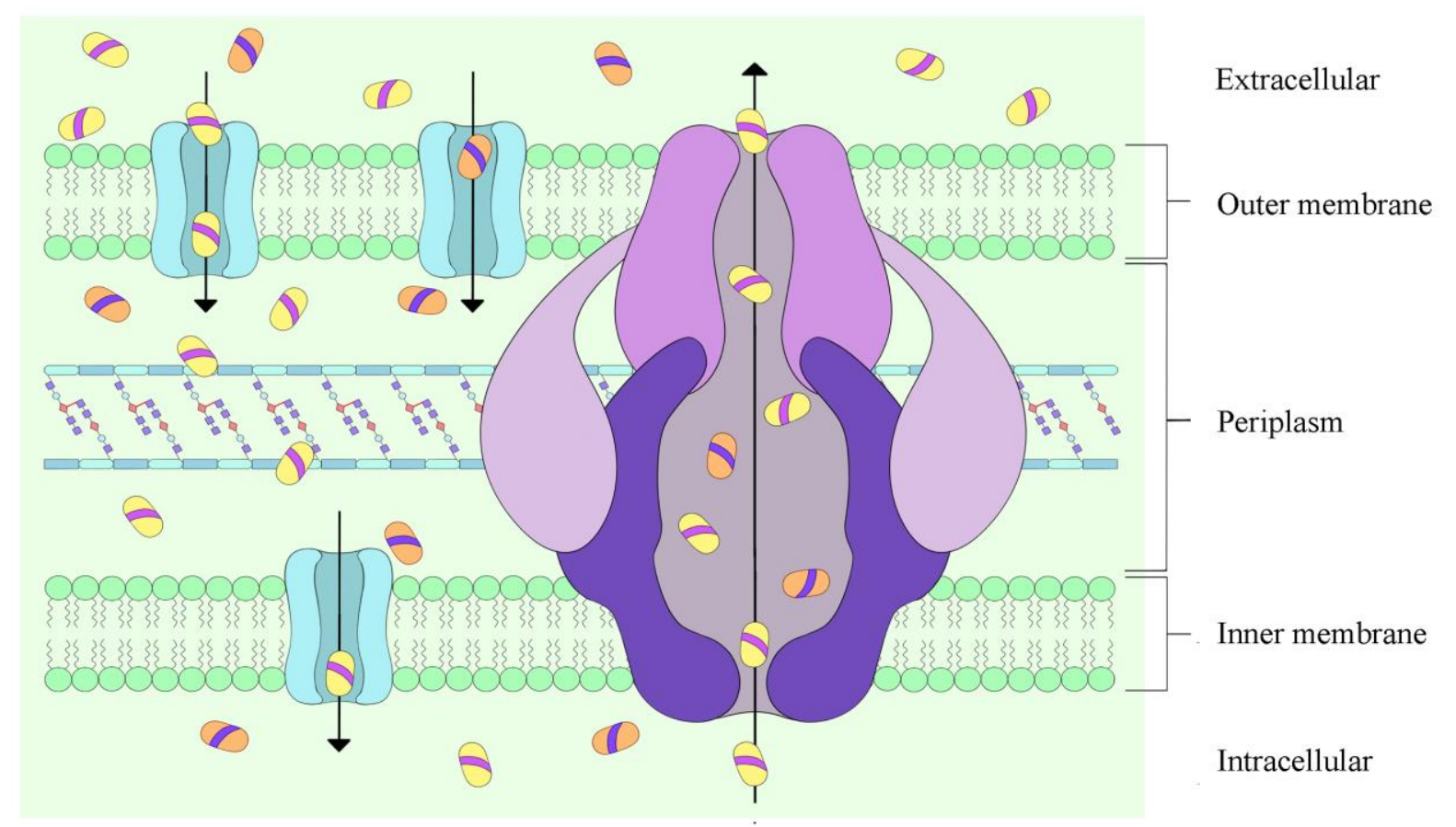

Figure 5. Generalized mechanism of non-specific multidrug efflux pumps belonging to the resistancenodulation-division (RND) family. Adapted from the literature [35]

The reduction of permeability in the outer membrane of bacteria is another strategy employed (Figure 6). Bacteria import and export small polar molecules, amino acids and nutrients from the environment via water-filled channel proteins known as porins. However, these hydrophilic porin channels also allow access to antibiotics such as penicillin $\mathrm{N}$ and cephalosporins which are hydrophilic. In order to prevent such an occurrence, bacteria can reduce and/or mute the expression of such porin protein channels and even modify the structure of the porin channels, reducing the permeability of these antibiotics. For example, drug resistant strains of E. coli and Enterobacter aerogenes have been shown to modify the structure of porins by narrowing the porin channel in order to reduce their permeability towards antibiotics while Klebsiella pneumoniae have been shown to reduce the expression of porins in minimizing the uptake of antibiotic molecules [36-38]. 


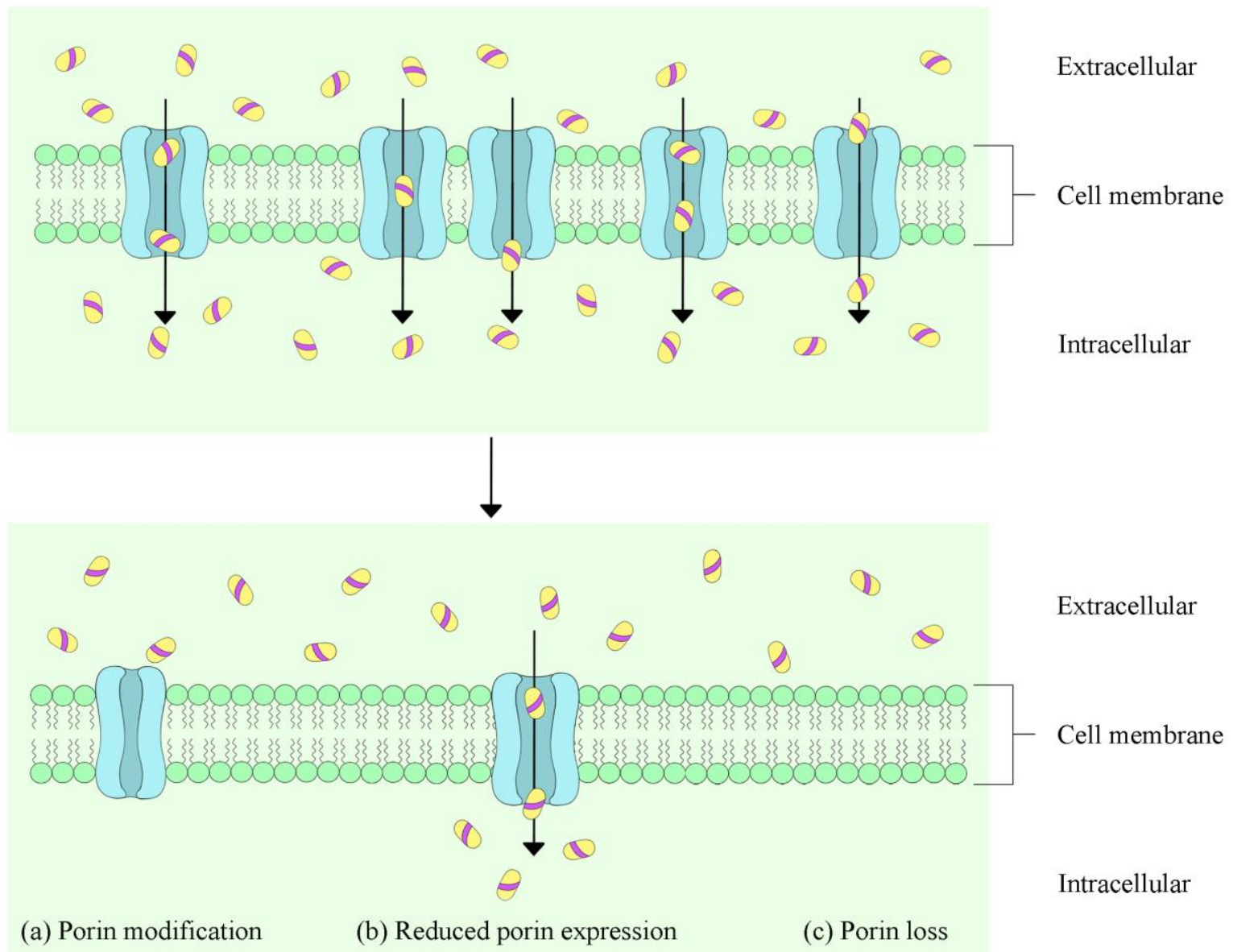

Figure 6. Generalized mechanisms for reduction in the permeability via gene mutation of porins in cell membrane. Adapted from the literature [39]

\subsection{Target/Substrate Overproduction}

Discovery of antibiotic modifiers such as the $\beta$-lactamase enzyme enabled combinatorial treatments involving antibiotics together with $\beta$-lactamase enzyme inhibitors as mentioned above. It is not surprising that bacteria eventually will develop resistance towards the inhibitor, given frequent administration of such combinations. This is in addition to the high mutational rates that the bacteria will be subjected to, due to direct effects exerted by both the antibiotic and inhibitor. As such, resistance to $\beta$-lactamase inhibitors can be developed with an overproduction of the target, the unmodified $\beta$-lactamase enzyme. This has been shown in drug resistant strains of $E$. coli and $K$. pneumoniae [40-41]. Another example is observed in the overexpression of the enzyme dihydrofolate reductase, which is crucial in the nucleic acid precursor synthesis in Mycobacterium tuberculosis and E. coli. This enzyme confers resistance to antimicrobial drugs such as para-aminosalicylic acid and trimethoprim [42-43].

\section{5. $\quad$ Remodeling of Cell Wall}

Under normal physiological conditions, the bacterial cell wall is constantly being remodeled, with the old peptidoglycan cell wall being broken down and replaced with new molecules. Antibiotics of the glycopeptide group mainly target construction of the bacterial cell wall. For instance, 
teicoplanin and vancomycin prevents the transpeptidation and transglycosylation via the action of glycosyltransferases and transpeptidases through binding to the peptidyl-D-Ala-D-Ala extremity of peptidoglycan precursor [44-45]. This prevents the bacterial cell from replacing its old peptidoglycan wall, which, due to treatment, is constantly being broken down, eventually lysing and killing the cell. It has been reported that vancomycin-resistant Enterococci $i$ sp. produces a modified peptidoglycan precursor, from peptidyl-D-Ala-D-Ala to peptidyl-D-Ala-D-Lac or peptidyl-D-Ala-D-Ser, which prevents the binding of the glycopeptide antibiotic [46-47]. Achieving such modifications require either the acquisition of genes and/or inherent genetic mutation. Genes such as the vanA cluster encodes two enzymes: VanH dehydrogenase, which converts pyruvate into D-Lac, and VanA ligase, which facilitates the esterification of D-Ala and D-Lac forming peptidyl-D-Ala-D-Lac [48-49]. These changes in the peptidoglycan precursor will disable the binding of glycopeptide antibiotics but not the glycosyltransferases and transpeptidases, allowing cell wall synthesis to occur [50]. Furthermore, a single amino acid mutation on the Dd1 ligase, which is responsible for the ligation of two D-Ala, enables it to now join D-Ala to D-Lac, thus conferring resistance towards glycopeptide antibiotics. This phenomenon had also previously been observed in a vancomycin resistant strain of E. coli [51]. The cell wall remodeling mechanism is illustrated in figure 7 below.

(A)

(B)
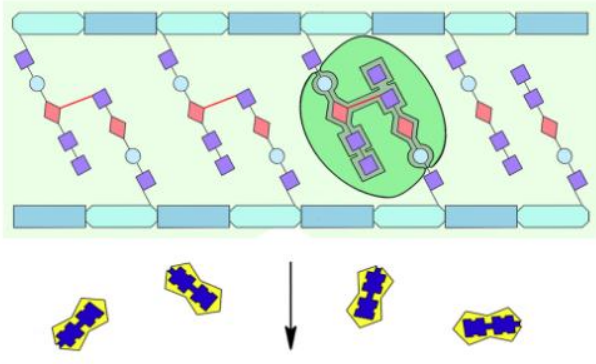

B)

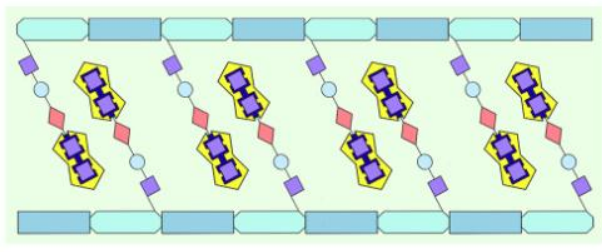

(C)

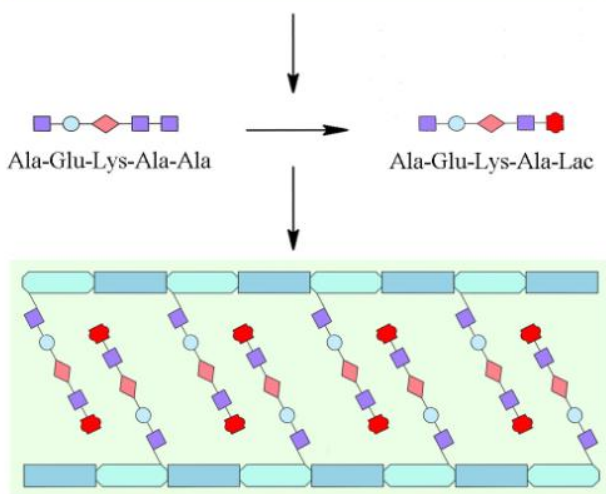

(D)
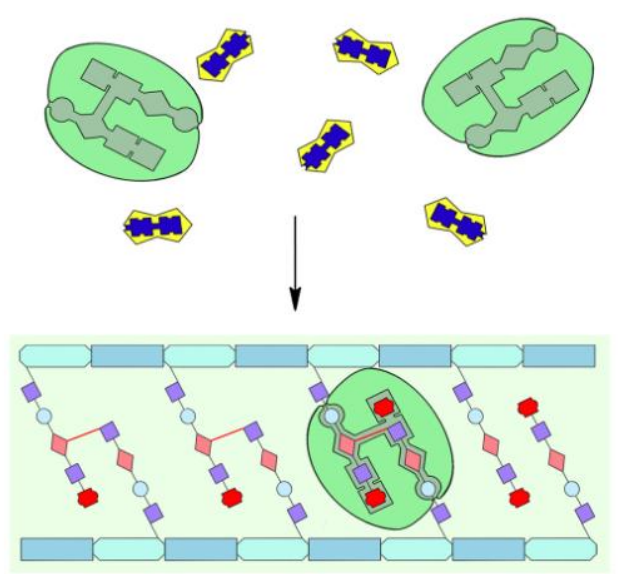

$\mathrm{N}$-acetylglucosamine

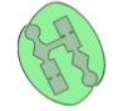

PBP

$\mathrm{N}$-acetylmuramic acid

L/D-alanine

L-lysine

D-glutamate

D-lactate

Vancomycin

(A) Cross-linking of peptidoglycan precursors between L-lysine and L/D-alanine via the action of PBP. (B) Inhibition of peptidoglycan cross-linking via high affinity binding of vancomycin towards peptidoglycan precursor, L/D-alanine moiety, preventing binding of PBP via steric hindrance. (C) Genetic mutation alters peptidoglycan precursor's amino acid moiety from $\mathrm{L} / \mathrm{D}$-alanine-L/D-alanine to $\mathrm{L} / \mathrm{D}$-alanine-L-lactate. (D) Change in amino acid moiety of the peptidoglycan precursor prevents the binding of vancomycin but allows the cross-linking action of PBP.

Figure 7. Substitution of amino acid in the peptidoglycan precursor reinstating normal function to PBP 


\section{Plant Secondary Metabolites as Antimicrobial Agent}

Plants produce a vast repertoire of secondary metabolites such as essential oils, alkaloids, terpenoids, phenolics and peptides in their normal metabolic pathways [52]. These metabolites play a major role in protecting the plant from microbial infection, pests, and UV radiation while attracting pollinators and seed-dispersing animals. In addition, certain metabolites act as crucial signalling agents in certain metabolic pathways, thus promoting the growth of the plant [53]. To date, over 100,000 plant secondary metabolites have been identified and majority of them play an important role in the immune system of the plant, exhibiting antimicrobial potentials [54]. Therefore, much work have been carried out in the hopes of discovery and development of more effective drugs from medicinal plant derivatives which will not confer resistance to pathogens, reduce toxicity in drug application, culminating into fewer side effects when compared to current synthetic drugs [55].

\subsection{Essential Oils}

Essential oils are characterized by their aromatic attributes, and are commonly used in the cosmetic and food industry. In addition, essential oils are also known for their antibacterial, antifungal and antiviral properties [56-58]. Generally, essential oils consist of 20 to 60 components which are highly volatile but none of which are actually lipid in nature; they are thus not considered true oils. The major chemical compounds which make up an essential oil can be categorized into three groups: terpenes and terpenoids and aromatic compounds. Terpenes have the base unit of five carbons known as an isoprene unit and can be categorized into different groups such as the monoterpenes (two $\mathrm{C}_{5}$ units), sesquiterpenes (three $\mathrm{C}_{5}$ units), diterpenes (four $\mathrm{C}_{5}$ units) etc. Terpenoids, on the other hand, are terpenes units containing oxygen. Common aromatic compounds within essential oils are known as phenylpropanoid, a derivative of phenylalanine [59]. Among all of the mentioned compounds, monoterpenes comprise $90 \%$ of the content within essential oils while the remaining $10 \%$ is a combination of other terpenes, terpenoid and aromatic compounds [60-61].

The antimicrobial properties of essential oils are mainly attributed to the presence of terpenes, terpenoids and aromatic compounds. The complex bioactive composition of essential oils interacts with multiple bacterial cellular targets instead of a particular single mode of action, thus inhibiting pathogens from acquiring resistance [62]. Bioactive monoterpenes such as thymol and carvacrol found mainly in thyme and oregano essential oil and phenylpropanoid such as eugenol found mainly in clove essential oil indicated substantial antimicrobial activities against both Gram-positive and negative bacteria. Lambert and colleagues (2001) reported that carvacol and thymol possess the ability to disintegrate the outer membrane of Gram-negative bacteria and disrupt the cell membrane of Grampositive bacteria, thus counteracting the 'reduced membrane permeability' mechanism employed by multidrug resistant strains [63]. Disturbances in the outer membrane cause conformational changes, leading to leakage of ions across the cell membrane. Besides that, disruption of the cell membrane also increases susceptibility of the bacteria towards the actions of other bioactive compounds. Yap et. al (2013) demonstrated complete annihilation of multidrug-resistant bacteria when treated with a particular combination of essential oil and antibiotic at a fairly low concentration. The significant reduction in the minimum inhibitory concentration obtained for both essential oils and antibiotics implicate that compounds such as carvacol and thymol within essential oils permeate the cell membrane of the bacteria to the actions of antibiotics [64]. In addition, phenylpropanoids such as eugenol and trans-cinnamaldehyde, commonly found in cinnamon essential oil are able to inactivate microbial enzymes by forming linkages via hydrogen, ionic and hydrophobic interactions, eventually leading to bacterial cell death [65-66]. Other monoterpenes such as carvone, limonene and 1, 8-cineole found commonly in eucalyptus and rosemary essential oil are known to affect the metabolism and growth rate of bacteria [67-68]. 
Table 1. Plant essential oils and their Minimum Inhibitory Concentration (MIC) against a panel of tested bacteria.

\begin{tabular}{|c|c|c|c|c|c|}
\hline \multirow{2}{*}{$\begin{array}{l}\text { Essential } \\
\text { Oil }\end{array}$} & \multirow{2}{*}{ Plant Species } & \multirow{2}{*}{ Bacteria } & \multicolumn{2}{|c|}{ MIC } & \multirow{2}{*}{ References } \\
\hline & & & $(\mathrm{mg} / \mathrm{mL})$ & $(\%)$ & \\
\hline \multirow[t]{4}{*}{ Basil } & Ocimum basilicum & E. coli & 0.5 & - & [69-72] \\
\hline & & K. pneumoniae & 0.75 & - & \\
\hline & & S. typhimurium & 0.25 & - & \\
\hline & & S. aureus & 0.125 & - & \\
\hline Cilantro/ & Coriandrum sativum & E. coli & 0.14 & - & {$[73,74]$} \\
\hline \multirow[t]{3}{*}{ Coriander } & & K. pneumoniae & 0.28 & - & \\
\hline & & L. monocytogenes & 0.2 & - & \\
\hline & & MRSA & 0.25 & - & \\
\hline \multirow[t]{4}{*}{ Cinnamon } & Cinnamomum zeylandicum & B. cereus & 2 & - & {$[64,75-78]$} \\
\hline & & E. coli & - & 0.078 & \\
\hline & & P. aeruginosa & - & 0.11 & \\
\hline & & S. mutans & 0.125 & - & \\
\hline \multirow[t]{4}{*}{ Clove } & Syzygium aromaticum & B. cereus & 2.75 & - & {$[76,78]$} \\
\hline & & E. coli & 4.5 & - & \\
\hline & & P. aeruginosa & - & 1.80 & \\
\hline & & S. aureus & 4.5 & - & \\
\hline \multirow[t]{4}{*}{ Garlic } & Allium sativum & A. tumefaciens & 0.3 & - & [79-81] \\
\hline & & E. coli $\mathrm{O} 128$ & 2.75 & - & \\
\hline & & S. aureus & 0.02 & - & \\
\hline & & S. flexneri & 1.37 & - & \\
\hline \multirow[t]{4}{*}{ Lavender } & Lavandula angustifolia & E. coli & - & 4 & {$[64,82,83]$} \\
\hline & & H. pylori & 2 & - & \\
\hline & & K. pneumoniae & 1.5 & - & \\
\hline & & MRSA & 2 & - & \\
\hline \multirow[t]{4}{*}{ Lemongrass } & Cymbopogon citratus & E. coli & - & 0.12 & {$[75,76,84]$} \\
\hline & & K. pneumoniae & - & 0.5 & \\
\hline & & L. monocytogenes & - & 0.75 & \\
\hline & & P. aeruginosa & - & 1.80 & \\
\hline \multirow[t]{4}{*}{ Oregano } & Origanum vulgare & C. perfringens & 5 & - & {$[85,86]$} \\
\hline & & E. coli & - & 0.37 & \\
\hline & & K. pneumoniae & - & 1 & \\
\hline & & $P$. aeruginosa & - & 2 & \\
\hline \multirow[t]{4}{*}{ Peppermint } & Mentha piperita & C. perfringens & 10 & - & {$[64,85,87,88]$} \\
\hline & & E. coli & - & 2 & \\
\hline & & MRSA & 0.064 & - & \\
\hline & & P. aeruginosa & - & 0.92 & \\
\hline \multirow[t]{4}{*}{ Tea Tree } & Melaleuca alternifolia & E. coli & - & 0.25 & {$[86,89]$} \\
\hline & & K. pneumoniae & - & 0.5 & \\
\hline & & P. aeruginosa & - & 1 & \\
\hline & & S. aureus & - & 0.5 & \\
\hline
\end{tabular}




\subsection{Alkaloids}

Due to an enormous pool in structural variety, alkaloids are often not classified into categories. In general, a compound that is heterocyclic, nitrogenous (at least one nitrogen derived from an amino acid) and has limited distribution within a plant is considered as an alkaloid. Among all screened alkaloids, the aaptamine, agelasine, indole, indolizidine, isoquinoline, piperazine, polyamine and quinolone exhibit antimicrobial potential [90-93]. However, alkaloids are not widely used for disease therapy because most of the compounds mentioned exhibit carcinogenic properties and may cause severe toxicity to humans [94-95]. Chelerythrine of the group isoquinoline and hapalindole of the group indole are a few exceptions which exhibit antimicrobial activity against drug resistant strains such as towards $P$. aeruginosa at low dosages but indicate no toxicity in Vero cells [96-97].

The mode of action of several alkaloid classes such as isoquinoline, and polyamine have been studied extensively fairly recently. It has been reported that isoquinoline such as chelerythrine possess two mechanisms in inhibiting the growth of bacterial cells; through inhibiting the cellular division and nucleic acid synthesis. Isoquinoline inhibits cellular division by tampering with the FtsZ protein, a protein which is essential for the $\mathrm{Z}$ ring formation during cellular division [98-99]. In addition, the synthesis of nucleic acids is also inhibited as isoquinoline inhibits the action of type I topoisomerases; this prevents the translation of antibiotic resistant genes, increasing bacterial susceptibility towards antibiotics [100]. Polyamine, on the other hand, compromises the integrity and stability of cell membrane, increasing the membrane permeability via depolarization, leading to leakage of the cytoplasmic contents and later, cell death [101-102].

Table 2 Alkaloids of plant origin and their MIC against a panel of tested bacteria.

\begin{tabular}{|c|c|c|c|c|}
\hline Alkaloid & Plant Specis & Bacteria & $\operatorname{MIC}(\mu \mathrm{g} / \mathrm{mL})$ & References \\
\hline \multirow[t]{4}{*}{ Agelasine D } & Agelas mauritiana & E. coli & 8 & {$[103,104]$} \\
\hline & & M. smegmatis & 0.8 & \\
\hline & & P. aeruginosa & 16 & \\
\hline & & S. pyogenes & 2 & \\
\hline \multirow[t]{2}{*}{ Ascididemin } & Didemnum rubeum & B. subtilis & 14 & {$[105,106]$} \\
\hline & & E. coli & 10 & \\
\hline \multirow[t]{4}{*}{ Berberine } & Berberis vulgaris & E. coli & 512 & {$[107,108]$} \\
\hline & & M. luteus & 512 & \\
\hline & & MRSA & 128 & \\
\hline & & P. aeruginosa & 256 & \\
\hline \multirow[t]{4}{*}{ Chelerythrine } & Chelidonium & B. subtilis & 1.5 & {$[96,109]$} \\
\hline & majus & E. coli & 2.5 & \\
\hline & & K. pneumoniae & 1.5 & \\
\hline & & S. pyogene & 1.5 & \\
\hline \multirow[t]{4}{*}{ Piperine } & Piper nigrum & B. subtilis & 312.5 & {$[110,111]$} \\
\hline & & E. coli & 625 & \\
\hline & & K. pneumoniae & 625 & \\
\hline & & MRSA & 100 & \\
\hline \multirow[t]{4}{*}{ Sanguinarine } & Sanguinaria & K. pneumonia & 16 & {$[112,113]$} \\
\hline & canadensis & MRSA & 1 & \\
\hline & & P. aeruginosa & 128 & \\
\hline & & S. pyogenes & 4 & \\
\hline
\end{tabular}




\subsection{Phenolics}

Phenolics are compounds which are structurally comprised of one or more aromatic rings with hydroxyl groups and can be classified into several groups such as phenolic acids, flavonoid, stilbenes, tannins, coumarin and etc [114-115]. These compounds are the major secondary metabolites in plants which are derived from the shikimate, pentose phosphate and phenylpropanoid pathways [116].

Table 3 Phenolic compounds of plant origin and their MIC against a panel of tested bacteria.

\begin{tabular}{|c|c|c|c|c|}
\hline Phenolic & Plant & Bacteria & $\underset{(\mathbf{m g} / \mathbf{m L})}{\mathrm{MIC}}$ & References \\
\hline \multirow[t]{4}{*}{ Caffeic Acid } & Eucalyptus globulus & B. cereus & 17.3 & {$[125]$} \\
\hline & & E. coli & 45.8 & \\
\hline & & P. aeruginosa & 72 & \\
\hline & & S. aureus & 8.6 & \\
\hline \multirow{4}{*}{ Catechin } & Acacia catechu & B. cereus & 6.4 & {$[126]$} \\
\hline & Camellia sinensis & B. subtilis & 12.8 & \\
\hline & & S. aureus & 12.8 & \\
\hline & & E. faecalis & 6.4 & \\
\hline \multirow{3}{*}{ Catechol } & Acacia catechu & E. coli & 1.25 & [127] \\
\hline & & P. mirabilis & 1.25 & \\
\hline & & P. aeruginosa & 2.5 & \\
\hline \multirow[t]{4}{*}{ Coumarin } & Dipteryx odorata & E. aerogenes & 0.625 & {$[128,129]$} \\
\hline & Galium odoratum & E. coli & 1.25 & \\
\hline & & S. aureus & 0.5 & \\
\hline & & S. typhimurium & 2.5 & \\
\hline \multirow[t]{4}{*}{ Gallic Acid } & Hamamelis virginiana & E. coli & 1.5 & {$[127,130]$} \\
\hline & Camellia sinensis & L. monocytogenes & 2 & \\
\hline & & P. mirabilis & 5 & \\
\hline & & P. aeruginosa & 5 & \\
\hline \multirow[t]{4}{*}{ Resveratrol } & Vitis vinifera & B. cereus & 0.05 & {$[131,132]$} \\
\hline & Vaccinium corymbosum & E. faecalis & 0.1 & \\
\hline & & MRSA & 0.2 & \\
\hline & & P. aeruginosa & 0.342 & \\
\hline \multirow[t]{4}{*}{ Rutin } & Carpobrotus edulis & A. baumannii & 8 & [133] \\
\hline & & E. coli & 16 & \\
\hline & & K. pneumoniae & 16 & \\
\hline & & $P$. aeruginosa & 16 & \\
\hline \multirow[t]{4}{*}{ Salicylic Acid } & Salix alba & E. coli & 3.2 & {$[134,135]$} \\
\hline & & K. pneumoniae & 0.031 & \\
\hline & & S. typhimurium & 0.25 & \\
\hline & & S. aureus & 1.6 & \\
\hline \multirow{4}{*}{$\begin{array}{l}\text { Tannin/Tannic } \\
\text { acid }\end{array}$} & Solanum trilobatum & E. coli & 4 & [136] \\
\hline & & P. aeruginosa & 4 & \\
\hline & & S. typhimurium & 2 & \\
\hline & & S. pyogenes & 2 & \\
\hline
\end{tabular}

Flavonoids, one of the natural phenolics, have been intensively studied for their antimicrobial potentials. They are ubiquitous in cells carrying out photosynthesis, and can be found easily in fruits, seeds, stems and flowers of a plant [117]. It has been reported that different flavonoids inhibit bacterial 
growth via different mechanisms. For instance, robinetin and myricetin exert their antimicrobial activity towards Proteus vulgaris and MRSA by intercalation of the nucleic acid bases which works to inhibit nucleic acid synthesis [118]. Ikigai et al (1993) reported that epigallocatechin gallate found in green tea, which disrupts the cytoplasmic membrane of MRSA, contributes to cytoplasmic leakage and grants easy access to antibiotics, eventually leading to cell death of the bacteria [119]. In addition, licochalcone is able to inhibit the bacterial respiratory electron transport chain by binding to cytochrome $c$ and CoQ as evidenced by a study done on Micrococcus luteus and MRSA [120].

Tannins are another phenolic compound which are water soluble and exhibit astringent properties in precipitating proteins and other organic compounds. They can be categorized into two groups: hydrolysable tannins and non-hydrolysable tannins. Hydrolysable tannins are made up of either gallic or ellagic acid ester and a polyol whereas non-hydrolysable tannins, otherwise known as catechol-type tannins, are made up of polymeric flavonoid molecules which do not contains sugar residues [121] Studies have shown that hydrolysable tannins such as gallotannin are bioactive against Streptococcus spp through the inhibition glucosyltransferase which is involved in the formation of biopolymer such as DNA, RNA and protein [122]. In addition, hydrolysable tannins also disrupt the peptidoglycan cell wall and cytoplasmic membrane of drug-resistant strain of Helicobacter pylori and Candida albicans, leading to the leakage of cellular content and cell death [123-124].

\section{Reversal of Antibiotic Resistance via Synergism}

With recent advances in science and technology, discovery of novel antibiotics are made more feasible. However, researchers have shifted their focus from discovering new drugs to discovering compounds of plant origin which may revive the efficacy of existing antibiotics through the means of synergism when lower concentrations of the antibiotic can be used.

Lorenzi and colleagues (2009) have demonstrated that essential oil from the curry plant Helichrysum italicum works synergistically with chloramphenicol, which when applied in combination, significantly reduces the dosage of the antibiotic needed to annihilate chloramphenicol resistant strains of Enterobacter aerogenes. When E. aerogenes was treated with chloramphenicol alone, its efflux pump was overexpressed. However, when applied in combination, the researchers found that the essential oil acts as an efflux pump inhibitor, preventing the removal of the chloramphenicol antibiotic enabling it to diffuse across the bacterial cell wall and cell membrane [137]. Besides that, it has also been reported that tea tree, Melaleuca alternifolia essential oil has the ability to permeate the bacterial cell wall and cell membrane of both Gram positive and negative bacteria, allowing for easier diffusion of antibiotics contributing to cellular content leakage, and eventually cell death [138-139]. In addition, the essential oils of cinnamon bark, Cinnamomum verum and lavender, Lavandula angustifolia have been shown to exhibit synergistic relationships with piperacillin when used against multidrug resistant E. coli [140-141]. Yap et al (2015) also postulated that such synergism arose from multiple compounds within the essential oil, which helped permeate the outer membrane, and to further inhibit the quorum sensing ability of the multidrug resistant $E$. coli.

Alkaloids such as tomatidine were shown to exhibit synergism in combination with gentamicin when used against MRSA. However, the exact mode of action of tomatidine has yet to be elucidated [142]. A majority of the alkaloid compounds, which had been discovered and studied, suggested that alkaloids possessed the universal ability to inhibit the efflux system of drug resistant bacteria. For instance, lysergol reacts synergistically to nalidixic acid, a quinolone antibiotic via the inhibition of the efflux pump when used against multidrug resistant E. coli [143].

Last but not least, phenolic compounds such as baicalin and epicatechin gallate were shown to exhibit synergism with $\beta$-lactam antibiotics when used against resistant strains of Gram-negative and positive bacteria such as E. coli and MRSA [144-146]. The mode of action postulated for both baicalin and epicatechin gallate involves the permeability capability as well as cytoplasmic membrane disruption which eventually led to cellular leakage $[119,144]$. Furthermore, synergistic relationships have been reported between phenolic compounds such as $p$-coumaric acid, sinapic acid, caffeic acid and taxifolin in combination with antibiotics such as ciprofloxacin and erythromycin when used against multidrug resistant Campylobacter jejuni. It has been confirmed that the mode of action of the mentioned phenolic compound involves the inhibition of the efflux system as well as additional permeability of the cellular membrane [147]. 
Table 4 Plant secondary metabolites which exhibit synergism with antibiotics against a panel of bacteria.

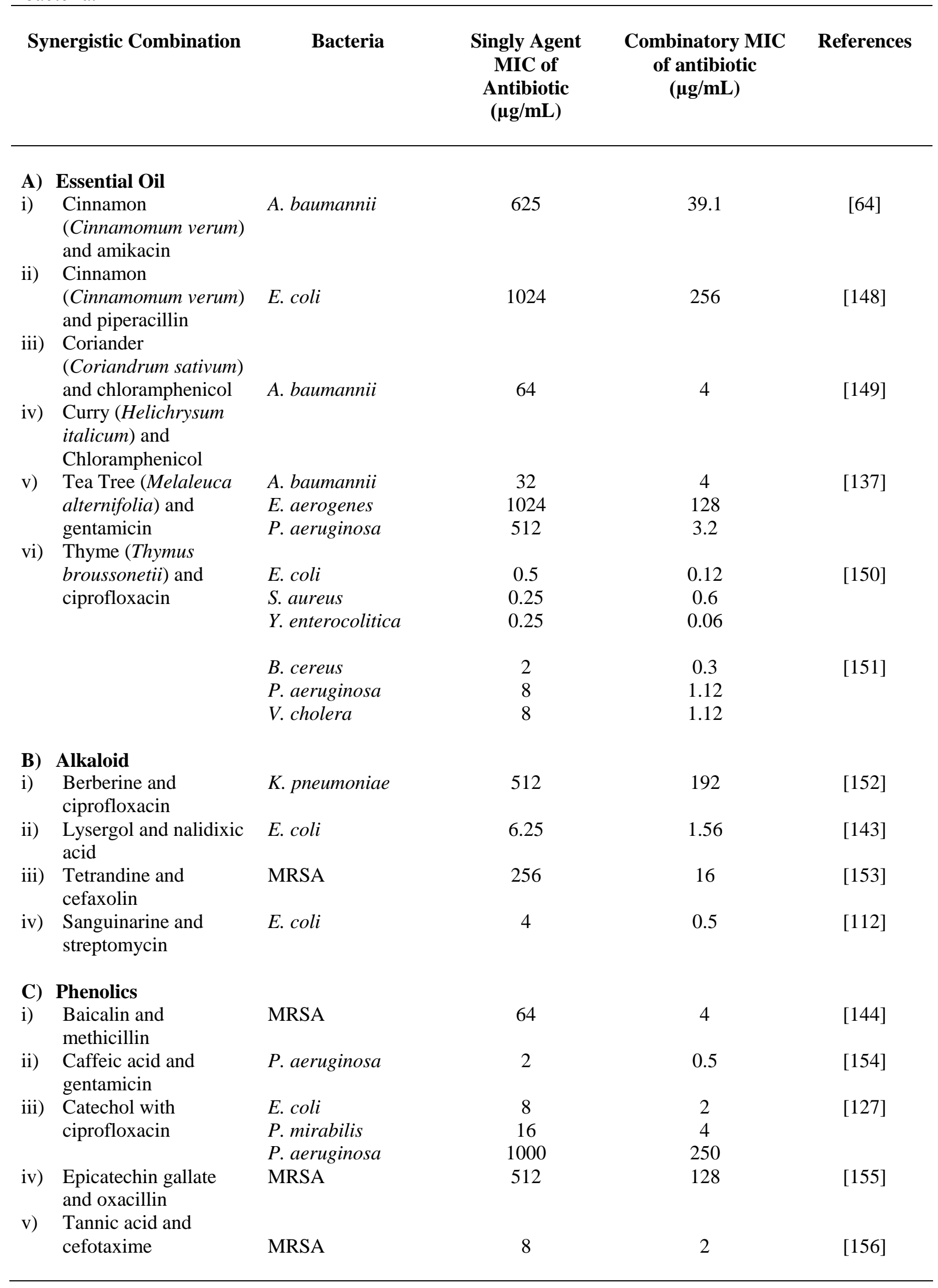




\section{Future Prospects}

Throughout the history of mankind, plants have always been the go-to source as remedy for the treatment of diseases, before and even after the discovery of antibiotics. For instance, colchicine amide derived from plant Colchicum autumnale is used in chemotherapy against cancer while ajmaline, a glucoside inhibitor of $\mathrm{Na} / \mathrm{K}$ ATPase, isolated from plant Rauwolfia serpentina is used to treat cardiac arrhythmias [157-158]. Unfortunately, the current repertoire of commercially available antibiotics are mostly of bacterial or fungal origin; the only commercial antibiotics of plant origin are artemisinin from plant Artemisia annua and quinine from plant Cinchona officinalis which were used to treat malarial infection [159-160]. This is mainly due to the fact that most plants do not produce highly potent secondary metabolites specific for antimicrobial purpose as they have other defense mechanisms available [54]. However, due to the emergence as well as wide spread of antibiotic resistant gene among the bacterial community, plants are also subjected to stress which causes them to produce more potent antimicrobial agents [161]. Therefore, it is more probable for one to discover novel antimicrobials from plant derivatives and it is likely that such samples may be collected from antibiotic-contaminated sites.

The existence of hidden gene and dual-use codons (duons) within a plant cell is another factor which explains minimal usage of plant-derived antimicrobials; this is because it greatly limits the variety of plant secondary metabolites. The eukaryotic cell's genetic materials are packaged into the chromosome by coiling onto histone proteins which forms nucleosomes condensed into its final form, the chromosome. According to Segal and colleagues (2006), different histone proteins coil with specific DNA sequence to form a nucleosome complex which obstructs the binding of polymerases [162]. The special positioning of this nucleosome complex possesses regulatory effects on the expression or repression of certain genes through recruitment of different regulatory proteins. Besides that, as different histone proteins demonstrates different affinity towards DNA sequences, access to binding sites of polymerase and other transcriptional factors are thus, limited [162]. Hidden codes within the DNA known as duons which possess two functions have been discovered recently, functioning as amino acid coding and a transcriptional factor recognition site. A duon regulates the expression or repression of genes and thus alters the variety secondary metabolite [163]. Thus, efforts can be redirected towards toward the study of gene regulation which will allow for the manipulation of genes to generate a greater variety of plant secondary metabolites that will possess promising antimicrobial potential.

Another important missing link contributing to the studies of plant-derived antimicrobials is the detailed mechanisms involved. In recent years, there have been countless publications involving plant secondary metabolites and their antimicrobial potentials. Unfortunately, most of these publications only looked into the isolation and purification of a particular compound followed by the assessment of their ability in inhibiting the growth for a limited panel of microorganisms. Of that, only a small fraction of those would include assays to a point where it is possible to postulate the mode of action of the plant secondary metabolites to allow further assessments of their cytotoxicity ex-vivo. Thus, the lack of information on the mode of action prevents replacement of antibiotics by usage of plant secondary metabolites. In order to properly assess this, several approaches might be considered for the elucidation of the in-depth mechanism of plant secondary metabolites for use as antimicrobial agents. One of the most prominent approaches that are available is through the employment of proteomic studies. Proteomic profiling has been the mainstream method that allows for comparison of proteomic expression between the treated and control group of cells; this will define the mode of action of plantderived antimicrobials and the pathways involved. Established methods for proteomic approaches include high resolution, two-dimensional gel electrophoresis and stable isotopic labeling method; both are followed by identification via mass spectrometry. In addition, transcriptomic approaches can also be used to further validate the proteomic data by looking into the gene expression profile for a particular identified protein. Quantitative reverse transcriptase polymerase chain reaction is among the popular methods performed to again access the gene expression levels between the treated and untreated groups, shedding light on the mode of action of the plant-derived antimicrobials. Other validation approaches that can be performed are the metabolomics approach which allows the profile elucidation of metabolic intermediate, secondary metabolites, hormones and other compounds. 
Established methods for metabolomics are divided into two groups: gas chromatography for volatile metabolites and liquid chromatography for non-volatile metabolites. Prior to separation via chromatography, separated metabolites are quantified and identified via mass spectrometry. Such profiling will provide a glimpse into the physiological status of the cells which, when combined with the data from other approaches, paints a more wholesome picture for the mechanism of the plantderived antimicrobials.

Utilizing fundamental knowledge in the mode of action of plant-derived antimicrobials will ultimately lead us to the development of novel and efficacious biomarkers, which can be used as effective therapeutic agents that may ultimately help in the revival of existing antibiotics through synergism.

\section{Acknowledgments}

This work was supported by the Malaysian Medical Association (MMA) Foundation and Universiti Putra Malaysia (UPM). SKY and LYL drafted the manuscript. CWM, KSL and KY edited the manuscript whereas SHEL significantly refined the manuscript.

\section{ORCID}

Shun Kai Yang: 0000-0002-9275-3653

Lee Yoon Low: 0000-0002-7366-9149

Polly Soo Xi Yap: 0000-0002-1615-3138

Khatijah Yusoff: 0000-0002-7683-4760

Chun Wai Mai: 0000-0001-6532-184X

Kok Song Lai: 0000-0002-1887-2232

Swee Hua Erin Lim: 0000-0001-5177-0257

\section{References}

[1] C. Zuchora-Walske (2013). Antibiotics. ABDO Publishing Company, Minneapolis, United States of America.

[2] A. Fleming (1929). On the antibacterial action of cultures of a penicillium, with special reference to their use in the isolation of B. influenza, Bull. World Health Org. 79, 780-790.

[3] E.P. Abraham and E. Chain (1988). An enzyme from bacteria able to destroy penicillin, Rev Infect Dis. 10, 677-678.

[4] K. Lewis (2013). Platforms for antibiotic discovery, Nat. Rev. Drug. Discovery. 12, 371-387.

[5] C.F. Amábile-Cuevas (2007). Antimicrobial resistance in bacteria. Horizon Bioscience, Wymondham, England.

[6] C. Darwin (2005). On natural selection. Penguin Books, London, United Kingdom.

[7] K. Drlica and D. Perlin (2011). Antibiotic resistance: understanding and responding to an emerging crisis. FT Press, Upper Saddle River, New Jersey, United States of America.

[8] P.S. Yap, B.C. Yiap, H.C. Ping and S.H. Lim (2014). Essential oils, a new horizon in combating bacterial antibiotic resistance, Open Microbiol. J. 8, 6-14.

[9] R.P. Ambler (1980). The structure of beta-lactamases, Philos. Trans. R. Soc. Lond. B. Biol. Sci. 289, 321331.

[10] M.P. Hacker, W.S. Messer and K.A. Bachmann (2009). Pharmacology: Principles and practice. Academic, Amsterdam, Netherland.

[11] J. Spencer, A.R. Clarke and T.R. Walsh (2001). Novel mechanism of hydrolysis of therapeutic betalactams by Stenotrophomonas maltophilia L1 metallo-beta-lactamase, J. Biol. Chem. 276, 33638-33644.

[12] S.M. Drawz and R.A. Bonomo (2010). Three decades of beta-lactamase inhibitors, Clin. Microbiol. Rev. 23, 160-201.

[13] K. Bush, C. Macalintal, B.A. Rasmussen, V.J. Lee and Y. Yang (1993). Kinetic interactions of tazobactam with beta-lactamases from all major structural classes, Antimicrob. Agents. Chemother. 37, 851-858.

[14] J.D. Buynak (2006). Understanding the longevity of the beta-lactam antibiotics and of antibiotic/betalactamase inhibitor combinations, Biochem. Pharmacol. 71, 930-940.

[15] B. Loder, G.G. Newton and E.P. Abraham (1961). The cephalosporin C nucleus (7-aminocephalosporanic acid) and some of its derivatives, Biochem. J. 79, 408-416.

[16] R.B. Morin, B.G. Jackson, E.H. Flynn, R.W. Roeske and S.L. Andrews (1969). Chemistry of cephalosporin antibiotics. XIV. The reaction of cephalosporin $\mathrm{C}$ with nitrosyl chloride, J. Am. Chem. Soc. 91, 1396-1400. 
[17] H.C. Neu (1992). Structure-activity relationships: biological, In: The Chemistry of $\beta$-Lactams, ed: M.I. Page, Springer, Dordrecht, Netherlands.

[18] G. Cabot, L. Zamorano, B. Moya, C. Juan, A. Navas, J. Blazquez and A. Oliver (2016). Evolution of Pseudomonas aeruginosa antimicrobial resistance and fitness under low and high mutation rates, Antimicrob. Agents Chemother. 60, 1767-1778.

[19] C. Goffin and J.M. Ghuysen (1998). Multimodular penicillin-binding proteins: an enigmatic family of orthologs and paralogs, Microbiol. Mol Biol. Rev. 62, 1079-1093.

[20] K. Poole (2004). Resistance to beta-lactam antibiotics, Cell. Mol. Life Sci. 61, 2200-2223.

[21] P. Macheboeuf, A.M. Di Guilmi, V. Job, T. Vernet, O. Dideberg and A. Dessen (2005). Active site restructuring regulates ligand recognition in class A penicillin-binding proteins, Proc. Natl. Acad. Sci. USA. 102, 577-582.

[22] E. Sacco, M. Cortes, N. Josseaume, L.B. Rice, J.L. Mainardi and M. Arthur (2014). Serine/threonine protein phosphatase-mediated control of the peptidoglycan cross-linking L,D-transpeptidase pathway in Enterococcus faecium, MBio . 5, e01446.

[23] J.H. Morais-Cabral, A.P. Jackson, C.V. Smith, N. Shikotra, A. Maxwell and R.C. Liddington (1997). Crystal structure of the breakage-reunion domain of DNA gyrase, Nature 388, 903-906.

[24] C.J. Willmott and A. Maxwell (1993). A single point mutation in the DNA gyrase A protein greatly reduces binding of fluoroquinolones to the gyrase-DNA complex, Antimicrob. Agents. Chemother. 37, 126-127.

[25] E.G. Kuiper and G.L. Conn (2014). Binding induced RNA conformational changes control substrate recognition and catalysis by the thiostrepton resistance methyltransferase (Tsr), J. Biol. Chem. 289, 26189-26200.

[26] L. Grise-Miron and L. Brakier-Gingras (1982). Effect of neomycin and protein S1 on the binding of streptomycin to the ribosome, Eur. J. Biochem. 123, 643-646.

[27] D. Moazed and H.F. Noller (1987). Interaction of antibiotics with functional sites in 16S ribosomal RNA, Nature 327, 389-394.

[28] F. Sun, Y. Ding, Q. Ji, Z. Liang, X. Deng, C.C. Wong, C. Yi, L. Zhang, S. Xie, S. Alvarez, L.M. Hicks, C. Luo, H. Jiang, L. Lan and C. He (2012). Protein cysteine phosphorylation of SarA/MgrA family transcriptional regulators mediates bacterial virulence and antibiotic resistance, Proc. Natl. Acad. Sci. USA. 109, 15461-15466.

[29] M. Zhou, L. Xie, Z. Yang, J. Zhou and J. Xie (2016). Lysine succinylation of Mycobacterium tuberculosis isocitrate lyase (ICL) fine-tunes the microbial resistance to antibiotics, J. Biomol. Struct. Dyn. 1-12.

[30] M. Goswami, M. Subramanian, R. Kumar, J. Jass and N. Jawali (2016). Involvement of antibiotic efflux machinery in glutathione-mediated decreased ciprofloxacin activity in Escherichia coli, Antimicrob. Agents. Chemother. 60(7), 4369-4374.

[31] T. Kohler, M. Michea-Hamzehpour, P. Plesiat, A.L. Kahr and J.C. Pechere (1997). Differential selection of multidrug efflux systems by quinolones in Pseudomonas aeruginosa, Antimicrob. Agents. Chemother. 41, 2540-2543.

[32] N. Masuda, E. Sakagawa, S. Ohya, N. Gotoh, H. Tsujimoto and T. Nishino (2000). Substrate specificities of MexAB-OprM, MexCD-OprJ, and MexXY-OprM efflux pumps in Pseudomonas aeruginosa, Antimicrob. Agents. Chemother. 44, 3322-3327.

[33] K. Okamoto, N. Gotoh and T. Nishino (2002). Alterations of susceptibility of Pseudomonas aeruginosa by overproduction of multidrug efflux systems, MexAB-OprM, MexCD-OprJ, and MexXY/OprM to carbapenems: substrate specificities of the efflux systems, J. Infect. Chemother. 8, 371-373.

[34] S. Santos Costa, M. Viveiros, A.E. Rosato, J. Melo-Cristino and I. Couto (2015). Impact of efflux in the development of multidrug resistance phenotypes in Staphylococcus aureus, BMC Microbiol. 15, 232.

[35] J.M.A. Blair, M.A.Webber, A.J. Baylay, D.O. Ogbolu and L.J.V. Piddock (2015). Molecular mechanisms of antibiotic resistance, Nat. Rev. Micro. 13, 42-51.

[36] E. De, A. Basle, M. Jaquinod, N. Saint, M. Mallea, G. Molle and J.M. Pages (2001). A new mechanism of antibiotic resistance in Enterobacteriaceae induced by a structural modification of the major porin, Mol. Microbiol. 41, 189-198.

[37] S. Gayet, R. Chollet, G. Molle, J.M. Pages and J. Chevalier (2003). Modification of outer membrane protein profile and evidence suggesting an active drug pump in Enterobacter aerogenes clinical strains, Antimicrob. Agents. Chemother. 47, 1555-1559.

[38] R. Melano, A. Corso, A. Petroni, D. Centron, B. Orman, A. Pereyra, N. Moreno and M. Galas (2003). Multiple antibiotic-resistance mechanisms including a novel combination of extended-spectrum betalactamases in a Klebsiella pneumoniae clinical strain isolated in Argentina, J. Antimicrob. Chemother. 52, 36-42.

[39] L. Fernandez and R.E. Hancock (2012). Adaptive and mutational resistance: role of porins and efflux pumps in drug resistance, Clin. Microbiol. Rev. 25, 661-681.

[40] R. Gheorghiu, M. Yuan, L.M. Hall and D.M. Livermore (1997). Bases of variation in resistance to betalactams in Klebsiella oxytoca isolates hyperproducing K1 beta-lactamase, J. Antimicrob. Chemother. 40, 533-541.

[41] P.J. Wu, K. Shannon and I. Phillips (1995). Mechanisms of hyperproduction of TEM-1 beta-lactamase by clinical isolates of Escherichia coli, J. Antimicrob. Chemother. 36, 927-939.

[42] J.V. Rodrigues, S. Bershtein, A. Li, E.R. Lozovsky, D.L. Hartl and E.I. Shakhnovich (2016). Biophysical principles predict fitness landscapes of drug resistance, Proc. Natl. Acad. Sci. USA. 113, 11. 
[43] J. Zheng, E.J. Rubin, P. Bifani, V. Mathys, V. Lim, M. Au, J. Jang, J. Nam, T. Dick, J.R. Walker, K. Pethe and L.R. Camacho (2013). para-Aminosalicylic acid is a prodrug targeting dihydrofolate reductase in Mycobacterium tuberculosis, J. Biol. Chem. 288, 23447-23456.

[44] J.M. Frere and B. Joris (1985). Penicillin-sensitive enzymes in peptidoglycan biosynthesis, Crit. Rev. Microbiol. 11, 299-396.

[45] P.E. Reynolds (1989). Structure, biochemistry and mechanism of action of glycopeptide antibiotics, Eur. J. Clin. Microbiol. Infect. Dis. 8, 943-950.

[46] M. Arthur, C. Molinas, F. Depardieu and P. Courvalin (1993). Characterization of Tn1546, a Tn3-related transposon conferring glycopeptide resistance by synthesis of depsipeptide peptidoglycan precursors in Enterococcus faecium BM4147, J. Bacteriol. 175, 117-127.

[47] D. Meziane-Cherif, P.J. Stogios, E. Evdokimova, O. Egorova, A. Savchenko and P. Courvalin (2015). Structural and functional adaptation of vancomycin resistance VanT Serine racemases, MBio. 6, e00806.

[48] M. Arthur, C. Molinas, T.D. Bugg, G.D. Wright, C.T. Walsh and P. Courvalin (1992). Evidence for in vivo incorporation of D-lactate into peptidoglycan precursors of vancomycin-resistant Enterococci, Antimicrob. Agents. Chemother. 36, 867-869.

[49] T.D. Bugg, G.D. Wright, S. Dutka-Malen, M. Arthur, P. Courvalin and C.T. Walsh (1991). Molecular basis for vancomycin resistance in Enterococcus faecium BM4147: biosynthesis of a depsipeptide peptidoglycan precursor by vancomycin resistance proteins VanH and VanA, Biochemistry 30, 1040810415.

[50] A. Bouhss, N. Josseaume, A. Severin, K. Tabei, J.E. Hugonnet, D. Shlaes, D. Mengin-Lecreulx, J. Van Heijenoort and M. Arthur (2002). Synthesis of the L-alanyl-L-alanine cross-bridge of Enterococcus faecalis peptidoglycan, J. Biol. Chem. 277, 45935-45941.

[51] I.S. Park, C.H. Lin and C.T. Walsh (1996). Gain of D-alanyl-D-lactate or D-lactyl-D-alanine synthetase activities in three active-site mutants of the Escherichia coli D-alanyl-D-alanine ligase B, Biochemistry 35, 10464-10471.

[52] D.S. Seigler (1998). Plant secondary metabolism. Kluwer Academic, Boston, United States of America.

[53] A. Crozier, M.N. Clifford and H. Ashihara (2006). Plant secondary metabolites : occurrence, structure and role in the human diet. Blackwell Pub, Ames, Iowa, United States of America.

[54] R.A. Dixon (2001). Natural products and plant disease resistance, Nature 411, 843-847.

[55] P.R. Rajan, M.R. Harishchandra and R.P. Singh Satyendrakumar (2012). Study of krimighna effect of nimba (Azadiracta indica A.Juss.) Patra as rakshoghna dhoopan by culture and sensitivity method W.S.R. to pyogenic bacteria, Int. Res. J. Pharmacy 3, 142-146.

[56] S.K. Yang, K. Yusoff, C.W. Mai, W.M. Lim, W.S. Yap, S.H.E. Lim and K.S. Lai (2017). Additivity vs synergism: investigation of the additive interaction of cinnamon bark oil and meropenem in combination therapy, Molecules 22(1): 1733.

[57] L. Cherrat, L. Espina, M. Bakkali, D. Garcia-Gonzalo, R. Pagan and A. Laglaoui (2014). Chemical composition and antioxidant properties of Laurus nobilis L. and Myrtus communis L. essential oils from Morocco and evaluation of their antimicrobial activity acting alone or in combined processes for food preservation, J. Sci. Food. Agric. 94, 1197-1204.

[58] P.S.X. Yap, S.K. Yang, K.S. Lai and S.H.E. Lim (2017). Essential oil: the ultimate solution to antimicrobial resistance in Escherichia coli?, In: Escherichia coli-recent advances on physiology, pathogenesis and biotechnology applications, ed: A. Samie, InTech, Rijeka, Croatia.

[59] K.J. Hart, D.R. Yáñez-Ruiz, S.M. Duval, N.R. Mcewan and C.J. Newbold (2008). Plant extracts to manipulate rumen fermentation, Anim. Feed. Sci. Tech. 147, 8-35.

[60] T.J. Betts (2001). Chemical characterisation of the different types of volatile oil constituents by various solute retention ratios with the use of conventional and novel commercial gas chromatographic stationary phases, J. Chromatogr. A. 936, 33-46.

[61] E.J. Bowles (2003). The chemistry of aromatherapeutic oils. Allen \& Unwin, Crows Nest, New South Wales, Australia.

[62] C. Benchaar, A.V. Chaves, G.R. Fraser, K.A. Beauchemin and T.A. Mcallister (2007). Effects of essential oils and their components on in vitro rumen microbial fermentation, Can. J. Anim. Sci. 87, 413-419.

[63] R.J. Lambert, P.N. Skandamis, P.J. Coote and G.J. Nychas (2001). A study of the minimum inhibitory concentration and mode of action of oregano essential oil, thymol and carvacrol, J. Appl. Microbiol. 91, 453-462.

[64] P.S. Yap, S.H. Lim, C.P. Hu and B.C. Yiap (2013). Combination of essential oils and antibiotics reduce antibiotic resistance in plasmid-conferred multidrug resistant bacteria, Phytomedicine 20, 710-713.

[65] B.J. Juven, J. Kanner, F. Schved and H. Weisslowicz (1994). Factors that interact with the antibacterial action of thyme essential oil and its active constituents, J. Appl. Bacteriol. 76, 626-631.

[66] B. Ouattara, R.E. Simard, R.A. Holley, G.J. Piette and A. Begin (1997). Antibacterial activity of selected fatty acids and essential oils against six meat spoilage organisms, Int. J. Food Microbiol. 37, 155-162.

[67] H. Imai, K. Osawa, H. Yasuda, H. Hamashima, T. Arai and M. Sasatsu (2001). Inhibition by the essential oils of peppermint and spearmint of the growth of pathogenic bacteria, Microbios. 106(1), 31-39.

[68] M. Marotti, R. Piccaglia, E. Giovanelli, S.G. Deans and E. Eaglesham (1994). Effects of planting time and mineral fertilization on peppermint (Mentha x piperita) essential oil composition and its biological activity, Flav. Frag. J. 9, 125-129.

[69] I. Gaio, A.G. Saggiorato, H. Treichel, A.J. Cichoski, V. Astolfi, R.I. Cardoso, G. Toniazzo, E. Valduga, N. Paroul and R.L. Cansian (2015). Antibacterial activity of basil essential oil (Ocimum basilicum L.) in Italian-type sausage, J. Verbrauchers. Lebensmittelsich. 10, 323-329. 
[70] M.A. Hossain, M.J. Kabir, S.M. Salehuddin, S.M. Rahman, A.K. Das, S.K. Singha, M.K. Alam and A. Rahman (2010). Antibacterial properties of essential oils and methanol extracts of sweet basil Ocimum basilicum occurring in Bangladesh, Pharm. Biol. 48, 504-511.

[71] A.I. Hussain, F. Anwar, S.T. Hussain Sherazi and R. Przybylski (2008). Chemical composition, antioxidant and antimicrobial activities of basil (Ocimum basilicum) essential oils depends on seasonal variations, Food Chem. 108, 986-995.

[72] S.M.D. Silveira, A. Cunha Júnior, G.N. Scheuermann, F.L. Secchi and C.R.W. Vieira (2012). Chemical composition and antimicrobial activity of essential oils from selected herbs cultivated in the South of Brazil against food spoilage and foodborne pathogens, Ciência Rural. 42, 1300-1306.

[73] A. Bag and R.R. Chattopadhyay (2015). Evaluation of synergistic antibacterial and antioxidant efficacy of essential oils of spices and herbs in combination, PLoS One. 10.

[74] F. Casetti, S. Bartelke, K. Biehler, M. Augustin, C.M. Schempp and U. Frank (2012). Antimicrobial activity against bacteria with dermatological relevance and skin tolerance of the essential oil from Coriandrum sativum L. fruits, Phytother. Res. 26, 420-424.

[75] G. Ozcan and N.N. Demirel-Zorba (2016). Combined effect of ultrasound and essential oils to reduce Listeria monocytogenes on fresh produce, Food Sci. Technol. Int. 22, 353-362.

[76] I. Utchariyakiat, S. Surassmo, M. Jaturanpinyo, P. Khuntayaporn and M.T. Chomnawang (2016). Efficacy of cinnamon bark oil and cinnamaldehyde on anti-multidrug resistant Pseudomonas aeruginosa and the synergistic effects in combination with other antimicrobial agents, BMC Complement. Altern. Med. 16, 158.

[77] D.K. Bardaji, E.B. Reis, T.C. Medeiros, R. Lucarini, A.E. Crotti and C.H. Martins (2016). Antibacterial activity of commercially available plant-derived essential oils against oral pathogenic bacteria, Nat. Prod. Res. 30, 1178-1181.

[78] S. Siddiqua, B.A. Anusha, L.S. Ashwini and P.S. Negi (2015). Antibacterial activity of cinnamaldehyde and clove oil: effect on selected foodborne pathogens in model food systems and watermelon juice, $J$. Food Sci. Technol. 52, 5834-5841.

[79] J.W. Kim, Y.S. Kim and K.H. Kyung (2004). Inhibitory activity of essential oils of garlic and onion against bacteria and yeasts, J. Food Prot. 67, 499-504.

[80] Z.M. Ross, E.A. O'gara, D.J. Hill, H.V. Sleightholme and D.J. Maslin (2001). Antimicrobial properties of garlic oil against human enteric bacteria: evaluation of methodologies and comparisons with garlic oil sulfides and garlic powder, Appl. Environ. Microbiol. 67, 475-480.

[81] H.R. Soltan, S.M. Ahmed and D.A. Emam (2016). Comparative antibacterial activity of garlic essential oil extracted by hydro-distillation and diethyl ether extraction methods on four pathogenic bacteria, $A d v$. Plant. Agric. Res. 4 (2),0013.2

[82] S. De Rapper, G. Kamatou, A. Viljoen and S. Van Vuuren (2013). The in vitro antimicrobial activity of Lavandula angustifolia essential oil in combination with other aroma-therapeutic oils, Evid. Based. Complement. Alternat. Med. 852049.

[83] H.G. Preuss, B. Echard, M. Enig, I. Brook and T.B. Elliott (2005). Minimum inhibitory concentrations of herbal essential oils and monolaurin for gram-positive and gram-negative bacteria, Mol. Cell. Biochem. 272, 29-34.

[84] M.I. Naik, B.A. Fomda, E. Jaykumar and J.A. Bhat (2010). Antibacterial activity of lemongrass (Cymbopogon citratus) oil against some selected pathogenic bacterias, Asian. Pac. J. Trop. Dis. 3, 535538.

[85] M. Radaelli, B.P. Da Silva, L. Weidlich, L. Hoehne, A. Flach, L.A.M.A. Da Costa and E.M. Ethur (2016). Antimicrobial activities of six essential oils commonly used as condiments in Brazil against Clostridium perfringens, Braz. J. Microbiol. 47, 424-430.

[86] H. Sakkas, P. Gousia, V. Economou, V. Sakkas, S. Petsios and C. Papadopoulou (2016). In vitro antimicrobial activity of five essential oils on multidrug resistant Gram-negative clinical isolates, $J$. Intercult. Ethnopharmacol. 5, 212-218.

[87] M.L. Tsai, C.T. Wu, T.F. Lin, W.C. Lin, Y.C. Huang and C.H. Yang (2013). Chemical composition and biological properties of essential oils of two mint species, Trop. J. Pharm. Res. 12, 577-582.

[88] J. Li, J. Dong, J.Z. Qiu, J.F. Wang, M.J. Luo, H.E. Li, B.F. Leng, W.Z. Ren and X.M. Deng (2011). Peppermint oil decreases the production of virulence-associated exoproteins by Staphylococcus aureus, Molecules . 16, 1642-1654.

[89] C.F. Carson, T.V. Riley (1994). The antimicrobial activity of tea tree oil, Med. J. Aust. 160, 236.

[90] L. Calcul, A. Longeon, A.A. Mourabit, M. Guyot and M.L. Bourguet-Kondracki (2003). Novel alkaloids of the aaptamine class from an Indonesian marine sponge of the genus Xestospongia, Tetrahedron 59, 6539-6544.

[91] W. Maneerat, W. Phakhodee, T. Ritthiwigrom, S. Cheenpracha, T. Promgool, K. Yossathera, S. Deachathai and S. Laphookhieo (2012). Antibacterial carbazole alkaloids from Clausena harmandiana twigs, Fitoterapia 83, 1110-1114.

[92] V. Samoylenko, M.K. Ashfaq, M.R. Jacob, B.L. Tekwani, S.I. Khan, S.P. Manly, V.C. Joshi, L.A. Walker and I. Muhammad (2009). Indolizidine, antiinfective and antiparasitic compounds from Prosopis glandulosa var. glandulosa, J. Nat. Prod. 72, 92-98.

[93] A.P. Nissanka, V. Karunaratne, B.M. Bandara, V. Kumar, T. Nakanishi, M. Nishi, A. Inada, L.M. Tillekeratne, D.S. Wijesundara and A.A. Gunatilaka (2001). Antimicrobial alkaloids from Zanthoxylum tetraspermum and caudatum, Phytochemistry 56, 857-861. 
[94] W.C. Evans, D. Evans and G.E. Trease (2009). Trease and Evans pharmacognosy. Saunders/Elsevier, Edinburgh, England.

[95] B.L. Stegelmeier, J.A. Edgar, S.M. Colegate, D.R. Gardner, T.K. Schoch, R.A. Coulombe and R.J. Molyneux (1999). Pyrrolizidine alkaloid plants, metabolism and toxicity, J. Nat. Toxins. 8, 95-116.

[96] L.D.C. Tavares, G. Zanon, A.D. Weber, A.T. Neto, C.P. Mostardeiro, I.B.M. Da Cruz, R.M. Oliveira, V. Ilha, I.I. Dalcol and A.F. Morel (2014). Structure-activity relationship of benzophenanthridine alkaloids from Zanthoxylum rhoifolium having antimicrobial activity, PLoS ONE. 9, e97000.

[97] H. Kim, D. Lantvit, C.H. Hwang, D.J. Kroll, S.M. Swanson, S.G. Franzblau and J. Orjala (2012). Indole alkaloids from two cultured cyanobacteria, Westiellopsis sp. and Fischerella muscicola, Bioorg. Med. Chem. 20, 5290-5295.

[98] P.N. Domadia, A. Bhunia, J. Sivaraman, S. Swarup and D. Dasgupta (2008). Berberine targets assembly of Escherichia coli cell division protein FtsZ, Biochemistry 47, 3225-3234.

[99] J.M. Boberek, J. Stach and L. Good (2010). Genetic evidence for inhibition of bacterial division protein FtsZ by berberine, PLoS One. 5, e13745.

[100] L. Casu, F. Cottiglia, M. Leonti, A. De Logu, E. Agus, Y.C. Tse-Dinh, V. Lombardo and C. Sissi (2011). Ungeremine effectively targets mammalian as well as bacterial type I and type II topoisomerases, Bioorg. Med. Chem. Lett. 21, 7041-7044.

[101] K. Alhanout, S. Malesinki, N. Vidal, V. Peyrot, J.M. Rolain and J.M. Brunel (2010). New insights into the antibacterial mechanism of action of squalamine, J. Antimicrob. Chemother. 65, 1688-1693.

[102] X. Wang, X. Yao, Z. Zhu, T. Tang, K. Dai, I. Sadovskaya, S. Flahaut and S. Jabbouri (2009). Effect of berberine on Staphylococcus epidermidis biofilm formation, Int. J. Antimicrob. Agents. 34, 60-66.

[103] M. Arai, Y. Yamano, A. Setiawan and M. Kobayashi (2014). Identification of the target protein of agelasine D, a marine sponge diterpene alkaloid, as an anti-dormant mycobacterial substance, Chembiochem. 15, 117-123.

[104] A. Vik, E. Hedner, C. Charnock, O. Samuelsen, R. Larsson, L.L. Gundersen and L. Bohlin (2006). (+)agelasine D: improved synthesis and evaluation of antibacterial and cytotoxic activities, J. Nat. Prod. 69, 381-386.

[105] K.M. Marshall and L.R. Barrows (2004). Biological activities of pyridoacridines, Nat. Prod. Rep. 21, 731-751.

[106] N. Bontemps, D. Bry, S. Lopez-Legentil, A. Simon-Levert, C. Long and B. Banaigs (2010). Structures and antimicrobial activities of pyridoacridine alkaloids isolated from different chromotypes of the ascidian Cystodytes dellechiajei, J. Nat. Prod. 73, 1044-1048.

[107] S.Q. Wen, P. Jeyakkumar, S.R. Avula, L. Zhang and C.H. Zhou (2016). Discovery of novel berberine imidazoles as safe antimicrobial agents by down regulating ROS generation, Bioorg. Med. Chem. Lett. 26, 2768-2773.

[108] P. Jeyakkumar, L. Zhang, S.R. Avula and C.H. Zhou (2016). Design, synthesis and biological evaluation of berberine-benzimidazole hybrids as new type of potentially DNA-targeting antimicrobial agents, Eur. J. Med. Chem. 122, 205-215.

[109] F. Miao, X.J. Yang, L. Zhou, H.J. Hu, F. Zheng, X.D. Ding, D.M. Sun, C.D. Zhou and W. Sun (2011). Structural modification of sanguinarine and chelerythrine and their antibacterial activity, Nat. Prod. Res. 25, 863-875.

[110] B. Khameneh, M. Iranshahy, M. Ghandadi, D. Ghoochi Atashbeyk, B.S. Fazly Bazzaz and M. Iranshahi (2015). Investigation of the antibacterial activity and efflux pump inhibitory effect of co-loaded piperine and gentamicin nanoliposomes in methicillin-resistant Staphylococcus aureus, Drug. Dev. Ind .Pharm. 41, 989-994.

[111] Z. Zarai, E. Boujelbene, N. Ben Salem, Y. Gargouri and A. Sayari (2013). Antioxidant and antimicrobial activities of various solvent extracts, piperine and piperic acid from Piper nigrum, LWT-Food Sci. Technol. 50, 634-641.

[112] R. Hamoud, J. Reichling and M. Wink (2015). Synergistic antibacterial activity of the combination of the alkaloid sanguinarine with EDTA and the antibiotic streptomycin against multidrug resistant bacteria, $J$. Pharm. Pharmacol. 67, 264-273.

[113] B.W. Obiang-Obounou, O.H. Kang, J.G. Choi, J.H. Keum, S.B. Kim, S.H. Mun, D.W. Shin, K.W. Kim, C.B. Park, Y.G. Kim, S.H. Han and D.Y. Kwon (2011). The mechanism of action of sanguinarine against methicillin-resistant Staphylococcus aureus, J. Toxicol. Sci. 36, 277-283.

[114] P. Fresco, F. Borges, C. Diniz and M.P. Marques (2006). New insights on the anticancer properties of dietary polyphenols, Med. Res. Rev. 26, 747-766.

[115] W.Y. Huang, Y.Z. Cai and Y. Zhang (2010). Natural phenolic compounds from medicinal herbs and dietary plants: potential use for cancer prevention, Nutr. Cancer. 62, 1-20.

[116] R. Randhir, Y.T. Lin and K. Shetty (2004). Phenolics, their antioxidant and antimicrobial activity in dark germinated fenugreek sprouts in response to peptide and phytochemical elicitors, Asia Pac. J. Clin. Nutr. 13, 295-307.

[117] E.J.R. Middleton, C. Kandaswami and T.C. Theoharides (2000). The effects of plant flavonoids on mammalian cells: implications for inflammation, heart disease, and cancer, Pharmacol. Rev. 52, 673-751.

[118] A. Mori, C. Nishino, N. Enoki and S. Tawata (1987). Antibacterial activity and mode of action of plant flavonoids against Proteus vulgaris and Staphylococcus aureus, Phytochemistry 26, 2231-2234.

[119] H. Ikigai, T. Nakae, Y. Hara and T. Shimamura (1993). Bactericidal catechins damage the lipid bilayer, Biochem. Biophys. Acta. 1147, 132-136. 
[120] H. Haraguchi, K. Tanimoto, Y. Tamura, K. Mizutani and T. Kinoshita (1998). Mode of antibacterial action of retrochalcones from Glycyrrhiza inflate, Phytochemistry 48, 125-129.

[121] M. Sanz, E. Cadahia, E. Esteruelas, A.M. Munoz, B. Fernandez De Simon, T. Hernandez and I. Estrella (2010). Phenolic compounds in chestnut (Castanea sativa Mill.) heartwood. Effect of toasting at cooperage, J. Agric. Food Chem. 58, 9631-9640.

[122] C.D. Wu-Yuan, C.Y. Chen and R.T. Wu (1988). Gallotannins inhibit growth, water-insoluble glucan synthesis, and aggregation of mutans streptococci, J. Dent. Res. 67, 51-55.

[123] K. Funatogawa, S. Hayashi, H. Shimomura, T. Yoshida, T. Hatano, H. Ito and Y. Hirai (2004). Antibacterial activity of hydrolyzable tannins derived from medicinal plants against Helicobacter pylori, Microbiol. Immunol. 48, 251-261.

[124] S.H. Lim, I. Darah and K. Jain (2006). Antimicrobial activity of tannin extracted from Rhizophora apiculata barks, J. Trop. Forest. Sci. 18, 59-65.

[125] S. Meyuhas, M. Assali, M. Huleihil and M. Huleihell (2015). Antimicrobial activities of caffeic acid phenethyl ester, J. Mol. Biochem. 10, 21-31.

[126] K. Kajiya, H. Hojo, M. Suzuki, F. Nanjo, S. Kumazawa and T. Nakayama (2004). Relationship between antibacterial activity of (+)-catechin derivatives and their interaction with a model membrane, J. Agric. Food. Chem. 52, 1514-1519.

[127] V.B. Maisuria, Z. Hosseinidoust and N. Tufenkji (2015). Polyphenolic extract from maple syrup potentiates antibiotic susceptibility and reduces biofilm formation of pathogenic bacteria, Appl. Environ. Microbiol. 81, 3782-3792.

[128] L.W. Nitiema, A. Savadogo, J. Simpore, D. Dianou and A.S. Traore (2012). In vitro antimicrobial activity of some phenolic compounds (coumarin and quercetin) against gastroenteritis bacterial strains, Int. J. Microbiol Res. 3, 183-187.

[129] S.M. De Souza, F. Delle Monache and A.J.R. Smania (2005). Antibacterial activity of coumarins, $Z$. Naturforsch. C. 60, 693-700.

[130] A. Borges, C. Ferreira, M.J. Saavedra and M. Simoes (2013). Antibacterial activity and mode of action of ferulic and gallic acids against pathogenic bacteria, Microb. Drug. Resist. 19, 256-265.

[131] L. Paulo, S. Ferreira, E. Gallardo, J.A. Queiroz and F. Domingues (2010). Antimicrobial activity and effects of resveratrol on human pathogenic bacteria, World. J. Microbiol. Biotechnol. 26, 1533-1538.

[132] M.M. Chan (2002). Antimicrobial effect of resveratrol on dermatophytes and bacterial pathogens of the skin, Biochem. Pharmacol. 63, 99-104.

[133] D.D. Orhan, B. Özçelik, S. Özgen and F. Ergun (2010). Antibacterial, antifungal, and antiviral activities of some flavonoids, Microbiol. Res. 165, 496-504.

[134] J. Sahoo and S.K. Paidesetty (2015). Antimicrobial, analgesic, antioxidant and in silico study of synthesized salicylic acid congeners and their structural interpretation, Egyptian. J. Basi.c Appl. Sci. 2, 268-280.

[135] J. Monte, A.C. Abreu, A. Borges, L.C. Simões and M. Simões (2014). Antimicrobial activity of selected phytochemicals against Escherichia coli and Staphylococcus aureus and their biofilms, Pathogens 3, 473498.

[136] A. Doss, H.M. Mubarack and R. Dhanabalan (2009). Antibacterial activity of tannins from the leaves of Solanum trilobatum Linn, Ind. J. Sci. Tech. 2, 41-43

[137] V. Lorenzi, A. Muselli, A.F. Bernardini, L. Berti, J.M. Pages, L. Amaral and J.M. Bolla (2009). Geraniol restores antibiotic activities against multidrug-resistant isolates from gram-negative species, Antimicrob. Agents. Chemother. 53, 2209-2211.

[138] C.F. Carson, B.J. Mee and T.V. Riley (2002). Mechanism of action of Melaleuca alternifolia (tea tree) oil on Staphylococcus aureus determined by time-kill, lysis, leakage, and salt tolerance assays and electron microscopy, Antimicrob. Agents. Chemother. 46, 1914-1920.

[139] S.D. Cox, C.M. Mann, J.L. Markham, H.C. Bell, J.E. Gustafson, J.R. Warmington and S.G. Wyllie (2000). The mode of antimicrobial action of the essential oil of Melaleuca alternifolia (tea tree oil), $J$. Appl. Microbiol. 88, 170-175.

[140] P.S. Yap, T. Krishnan, K.G. Chan and S.H. Lim (2015). Antibacterial mode of action of Cinnamomum verum bark essential oil, alone and in combination with piperacillin, against a multi-drug-resistant Escherichia coli strain, J. Microbiol. Biotechnol. 25, 1299-1306.

[141] P.S. Yap, T. Krishnan, B.C. Yiap, C.P. Hu, K.G. Chan and S.H. Lim (2014). Membrane disruption and anti-quorum sensing effects of synergistic interaction between Lavandula angustifolia (lavender oil) in combination with antibiotic against plasmid-conferred multi-drug-resistant Escherichia coli, J. Appl. Microbiol. 116, 1119-1128.

[142] F. Chagnon, I. Guay, M.A. Bonin, G. Mitchell, K. Bouarab, F. Malouin and E. Marsault (2014). Unraveling the structure-activity relationship of tomatidine, a steroid alkaloid with unique antibiotic properties against persistent forms of Staphylococcus aureus, Eur. J. Med. Chem. 80, 605-620.

[143] A. Maurya, G.R. Dwivedi, M.P. Darokar and S.K. Srivastava (2013). Antibacterial and synergy of clavine alkaloid lysergol and its derivatives against nalidixic acid-resistant Escherichia coli, Chem. Biol. Drug. Des. 81, 484-490.

[144] I.X. Liu, D.G. Durham and R.M. Richards (2000). Baicalin synergy with beta-lactam antibiotics against methicillin-resistant Staphylococcus aureus and other beta-lactam-resistant strains of S. aureus, J. Pharm. Pharmacol. 52, 361-366.

[145] S. Shiota, M. Shimizu, T. Mizushima, H. Ito, T. Hatano, T. Yoshida and T. Tsuchiya (1999). Marked reduction in the minimum inhibitory concentration (MIC) of beta-lactams in methicillin-resistant 
Staphylococcus aureus produced by epicatechin gallate, an ingredient of green tea (Camellia sinensis), Biol. Pharm. Bull. 22, 1388-1390.

[146] P.D. Stapleton, S. Shah, J.C. Anderson, Y. Hara, J.M. Hamilton-Miller and P.W. Taylor (2004). Modulation of beta-lactam resistance in Staphylococcus aureus by catechins and gallates, Int. J. Antimicrob. Agents. 23, 462-467.

[147] E. Oh and B. Jeon (2015). Synergistic anti-Campylobacter jejuni activity of fluoroquinolone and macrolide antibiotics with phenolic compounds, Front. Microbiol. 6, 1129.

[148] F.Q. Guerra, J.M. Mendes, J.P. Sousa, M.F. Morais-Braga, B.H. Santos, H.D. Melo Coutinho and O. Lima ede (2012). Increasing antibiotic activity against a multidrug-resistant Acinetobacter spp by essential oils of Citrus limon and Cinnamomum zeylanicum, Nat. Prod. Res. 26, 2235-2238.

[149] A. Duarte, S. Ferreira, F. Silva and F.C. Domingues (2012). Synergistic activity of coriander oil and conventional antibiotics against Acinetobacter baumannii, Phytomedicine 19, 236-238.

[150] A. Rosato, M. Piarulli, F. Corbo, M. Muraglia, A. Carone, M.E. Vitali and C. Vitali (2010). In vitro synergistic antibacterial action of certain combinations of gentamicin and essential oils, Curr. Med. Chem. 17, 3289-3295.

[151] M. Fadli, A. Saad, S. Sayadi, J. Chevalier, N.E. Mezrioui, J.M. Pages and L. Hassani (2012). Antibacterial activity of Thymus maroccanus and Thymus broussonetii essential oils against nosocomial infection bacteria and their synergistic potential with antibiotics, Phytomedicine 19, 464-471.

[152] X.Y. Zhou, X.G. Ye, L.T. He, S.R. Zhang, R.L. Wang, J. Zhou and Z.S. He (2016b). In vitro characterization and inhibition of the interaction between ciprofloxacin and berberine against multidrugresistant Klebsiella pneumoniae, J. Antibiot. 69, 741-746.

[153] G.Y. Zuo, Y. Li, T. Wang, J. Han, G..C. Wang, Y.L. Zhang and W.D. Pan (2011). Synergistic antibacterial and antibiotic effects of bisbenzylisoquinoline alkaloids on clinical isolates of methicillin-resistant Staphylococcus aureus (MRSA), Molecules 16, 9819-9826.

[154] M.K. Sakharkar, P. Jayaraman, W.M. Soe, V.T. Chow, L.C. Sing and K.R. Sakharkar (2009). In vitro combinations of antibiotics and phytochemicals against Pseudomonas aeruginosa, J. Microbiol. Immunol. Infect. 42, 364-370.

[155] R. Qin, K. Xiao, B. Li, W. Jiang, W. Peng, J. Zheng and H. Zhou (2013). The combination of catechin and epicatechin callate from Fructus Crataegi potentiates beta-lactam antibiotics against methicillin-resistant Staphylococcus aureus (MRSA) in vitro and in vivo, Int. J. Mol. Sci. 14, 1802-1821.

[156] B.M. Kyaw, S. Arora and C.S. Lim (2012). Bactericidal antibiotic-phytochemical combinations against methicillin resistant Staphylococcus aureus, Braz. J. Microbiol. 43, 938-945.

[157] V. Bazika (1969). Ajmaline, an alkaloid of Rauwolfia serpentina, in the treatment of cardiac arrhythmias, Vnitr. Lek. 15, 662-670.

[158] D.H. Li, S.K. Zhang, Z.G. Hao, K.S. Ma, X.R. Tan, Z.L. Wang and N.K. Li (1980). Pharmacologic study of colchicine-amide, Chin. Med. J. (Engl). 93, 188-190.

[159] G.M. Findlay and A.C. Stevenson (1944). Investigations in the chemotherapy of malaria in West Africa, Ann. Trop. Med. Parasit. 38, 168-187.

[160] L.H. Miller and X. Su (2011). Artemisinin: discovery from the Chinese herbal garden, Cell 146, 855-858.

[161] K. Lewis and F.M. Ausubel (2006). Prospects for plant-derived antibacterials, Nat. Biotech. 24, 15041507.

[162] E. Segal, Y. Fondufe-Mittendorf, L. Chen, A. Thastrom, Y. Field, I.K. Moore, J.P.Z. Wang and J. Widom (2006). A genomic code for nucleosome positioning, Nature 442, 772-778.

[163] A.B. Stergachis, E. Haugen, A. Shafer, W. Fu, B. Vernot, A. Reynolds, A. Raubitschek, S. Ziegler, E.M. Leproust, J.M. Akey and J.A. Stamatoyannopoulos (2013). Exonic transcription factor binding directs codon choice and affects protein evolution, Science 342, 1367-1372.

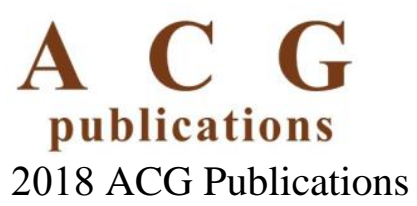

